\title{
A PANDEMIA E AS NOSSAS DESIGUALDADES DURADOURAS ${ }^{1}$
}

PANDEMIC AND OUR LASTING INEQUALITIES

\author{
Rogério de Souza Medeiros * \\ Mediadora: Simone Brito **
}

\begin{abstract}
Resumo
O artigo é uma versão ligeiramente modificada da palestra proferida em 11 de agosto de 2020 no "Seminário Ciências Sociais em Debate: crise e crítica social em tempos de Covid-19", promovido pelo Departamento de Ciências Sociais da UFPB. Ao final da palestra, o autor respondeu a perguntas, que foram lidas pela mediadora do evento, a professora Simone Brito (DCS/PPGS/UFPB). Na palestra, o autor buscou refletir sobre caminhos explorados pela sociologia para abordar a relação entre a pandemia e as desigualdades sociais. Nesse sentido, o autor procura construir uma interpretação sociológica a partir de alguns conceitos e abordagens presentes no campo de estudos sobre desigualdades sociais para defender o argumento acerca da existência de um paralelo forte entre a forma como os brasileiros toleram os altos índices de desigualdade presentes na história do país e a forma como temos normalizado alto número de vítimas fatais decorrente da pandemia de Covid-19.
\end{abstract}

Palavras-chave: Desigualdade Social; Pobreza; Pandemia; Cidadania.

\begin{abstract}
The article is a slightly modified version of the lecture given on August 11, 2020 at the "Seminar Social Sciences in Debate: crisis and social criticism in Covid-19 times", promoted by the Department of Social Sciences at UFPB. At the end of the lecture, the author answered questions, which were read by the event's mediator, Teacher Simone Brito (DCS / PPGS / UFPB). In the lecture, the author sought to reflect on ways explored by Sociology to address the relationship between the pandemic and social inequalities. In this sense, the author seeks to build a sociological interpretation from some concepts and approaches present in the field of studies on social inequalities to defend the argument about the existence of a strong parallel between the way

\footnotetext{
${ }^{1}$ Esse texto é uma versão ligeiramente modificada da palestra proferida em 11 de agosto de 2020 no "Seminário Ciências Sociais em Debate: crise e crítica social em tempos de Covid-19", promovido pelo Departamento de Ciências Sociais da UFPB, disponibilizada em https://www.youtube. $\mathrm{com} /$ watch? $\mathrm{v}=$ CAljbZEQ6rs. Ao final da palestra, o autor respondeu a perguntas, que foram lidas pela mediadora do evento, a profa. Simone Brito (DCS/PPGS/UFPB). O autor agradece a generosidade de Giovanni Boaes e José Adailton Vieira Aragão Melo, editores da revista, por terem providenciado a transcrição da palestra.

* PhD em Sociologia pela Boston University/EUA. Professor do Departamento de Ciências Sociais e do Programa de Pós-Graduação em Sociologia (PPGS/UFPB)/Brasil. Coordenador e pesquisador do Grupo de Estudos e Pesquisas em Sociologia Política (GRESP/UFPB)/Brasil. E-mail: medeirosrogerio@hotmail.com.

** $\mathrm{PhD}$ em Sociologia pela Lancaster University/Inglaterra. Professora do Departamento de Ciências Sociais e do Programa de Pós-Graduação em Sociologia (PPGS/UFPB)/Brasil. Coordenadora e pesquisador do Grupo de Estudos e Pesquisas em Sociologia Política (GRESP/UFPB)/Brasil. E-mail: simonebritto@hotmail.com.
} 
Brazilians tolerate the high rates of inequality present in the country's history and the way in which we have normalized a high number of fatalities resulting from the Covid-19 pandemic.

Keywords: Social Inequality; Poverty; Pandemic; Citizenship.

É uma satisfação participar desta atividade que o Departamento de Ciências Sociais da UFPB programou para esse período em que estamos trabalhando em regime remoto. É uma alegria poder fazer parte de uma atividade que tem demonstrado resultados muito interessantes. Eu acompanhei algumas das palestras dos nossos colegas professores que estavam listados no ciclo de palestras e se dispuseram a desenvolver reflexões sobre esse período da pandemia, e hoje a gente chega ao final. Calhou de eu estar aqui hoje como último palestrante desse ciclo.

O que me proponho a fazer na atividade de hoje é apresentar uma reflexão sobre esses temas, essas temáticas que foram negociadas entre os professores palestrantes e a chefia do departamento. Eu aqui quero agradecer publicamente por essa inciativa, todo esse trabalho de organização, na pessoa da professora Patrícia Ramiro, chefe do nosso departamento, e quero enfatizar a colaboração valiosíssima do professor Nino Amorim, que está aqui conosco, nos bastidores de todas as transmissões. Ele é o responsável por isso acontecer. A tecnologia não trabalharia para nós se não fosse Nino. Finalmente, agradeço a generosidade da Profa. Simone Brito, minha colega de departamento e de pósgraduação, que aceitou o convite para mediar este evento.

Então, as temáticas que foram desenvolvidas aqui pelos professores ao longo deste ciclo de palestras são o resultado de um trabalho de negociação e sugestão entre os professores, dentro dos campos em que desenvolvem suas atividades acadêmicas, e a forma como isso foi compondo um mosaico de temas que mostrasse um pouco como o Departamento de Ciências Sociais, além de estar tocando suas atividades rotineiras, com muito trabalho realizado de forma remota, também tem buscado dar visibilidade a todo esse trabalho por meio das mídias sociais. Eu sugeri este tema, e a coordenação do evento achou que seria interessante, que é "A pandemia e as nossas desigualdades duradouras".

Durante a abertura do evento, Simone comentou que eu venho trabalhando com o tema da desigualdade, com o tema das políticas de combate à pobreza e às desigualdades. E é por isso que hoje eu venho aqui falar desse assunto, ao qual eu venho me dedicando há algum tempo. No entanto, hoje eu não pretendo apresentar os resultados de nenhuma 
pesquisa específica, embora a minha fala, de certa forma, seja informada por essas atividades, informada por essas leituras e esse conjunto de conhecimentos que tem sido produzido desde que entramos nessa situação, de uma pandemia que tem levado a uma série de rupturas nas atividades mais distintas, das atividades econômicas, mas também impactado todas as nossas atividades intelectuais e acadêmicas. Todos os ramos da atividade humana foram afetados direta ou indiretamente por essa pandemia. Eu queria trazer um conjunto de reflexões acerca da pandemia e das desigualdades sociais.

O que é que estou propondo exatamente aqui hoje? Eu vou tentar apresentar algumas reflexões relativamente abrangentes sobre como temos pensado a pandemia desde que começou o período de isolamento, a quarentena. Tentarei passar de uma leitura, vamos dizer assim, mais cotidiana, corriqueira, sobre o que tem ocorrido na pandemia em termos de desigualdades, até uma leitura um pouco mais aprofundada, propondo, na verdade, um panorama acerca de como a sociologia ajuda a pensar a relação entre a pandemia e as desigualdades. Basicamente, é isso que eu vou tentar fazer. Não vou fazer nenhum levantamento abrangente, nenhuma revisão ampla de literatura, mas o título da minha palestra em si já traz uma proposta de abordagem do tema da desigualdade, à luz do momento da pandemia, que é a ideia de desigualdade duradora, desigualdades persistentes.

Vou tentar construir, em cima de evidências observáveis nos meios de comunicação, nas manchetes de jornal, nos editoriais de jornais e telejornais, ou nos blogs e nos vários podcasts que têm ampliado a discussão acerca da pandemia e das desigualdades sociais no Brasil, um argumento que possa, na verdade, fomentar um debate. E com isso, junto com aqueles e aquelas que estão nos assistindo, ir construindo uma conversa acerca de como as ciências sociais de modo geral, e como a sociologia, de maneira mais específica, tratam essa relação, ou podem tratá-la, entre a pandemia e as desigualdades sociais.

A gente viu - quem esteve atento a isso - que no início dessa quarentena, existia uma narrativa muito comum que circulava nas conversas por meio das redes sociais, de que a pandemia, de certa forma, nos igualava a todos. Estaríamos todos envolvidos numa situação de vulnerabilidade. A ideia de que a pandemia foi uma espécie de choque, que igualou todo mundo, foi sintetizada na expressão de que "estamos todos no mesmo barco". Uma série de campanhas publicitárias e outras formas de comunicação levaram 
em consideração essa elaboração discursiva. Quer dizer, existiu primeiro essa narrativa de que a pandemia era um fato tão chocante, tão impactante, que revelava essa igualdade básica, de que todas as pessoas do mundo estão igualmente vulneráveis. Acho até compreensível que tenhamos iniciado o debate público com esse tipo de narrativa, afinal de contas existe algo comum nisso tudo, somos todos seres humanos que estamos, por definição, sujeitos a sermos infectados por esse vírus. No entanto, não é nenhuma surpresa para qualquer cientista social perceber que, como quase todos os fenômenos coletivos, as pandemias não afetam os grupos sociais, as pessoas pertencentes a esses grupos sociais, de maneira igual.

Na verdade, a gente tem uma desigualdade muito grande na forma como esse vírus incide, como ele ameaça a vida a partir das várias condições que constituem grupos sociais na sociedade. Por exemplo, eu me lembro que no início, quando ainda corria de forma inquestionada a ideia de que a pandemia igualava todo mundo, as pessoas usando a ideia de que nos bairros de classe média alta a incidência era muito grande e o nível de contágio era bem elevado, como se isso fosse um indicador de que a doença não afetaria só os mais pobres, os mais vulneráveis socialmente. Qualquer pessoa que esteja acostumada a ver com um pouco mais de cuidado - me refiro mais particularmente aos cientistas sociais treinados para isso - consegue perceber que toda a dinâmica subjacente a esse dado mais cru, de que um bairro de classe média alta está sujeito a alta contaminação e disseminação do vírus, na verdade ajuda a compreender o funcionamento das formas de desigualdade ali predominantes. Existe uma série de dinâmicas, em termos de relações de trabalho, da inevitabilidade da manutenção da atividade econômica, mesmo sendo recomendado o isolamento, das necessidades da população em continuar trabalhando, que explica como é que esses bairros são todos atravessados por relações de dominação, todas as formas desiguais, assimétricas de poder que fazem com que o vírus se dissemine de maneira um pouco mais intensa nos lugares onde essas relações se dão de maneira mais intensa. Se a gente pensar na relação entre trabalhadores domésticos e seus empregadores, em nenhum lugar isso acontece de forma mais intensa do que num bairro de classe média ou classe média alta.

Então quem tem o olho treinado percebe que aquele indicador, que parecia demonstrar uma igualdade de condições, revelava uma série de dinâmicas sociais que 
escondiam o porquê desses bairros estarem bem no centro das primeiras ondas de disseminação da doença.

Em seguida, começamos a ver que o vírus circulava de maneira mais intensa em algumas situações, em algumas configurações geográficas, na separação entre o rural e o urbano, e fomos vendo, de forma cada vez mais evidente, que a pandemia não incide da mesma forma, nem com a mesma intensidade e nem com a mesma gravidade, quando observamos os diferentes grupos e suas diferentes condições. ${ }^{2}$

Eu queria aprofundar um pouco mais essa conversa pensando em como a desigualdade e a pobreza são dois traços muito antigos na história do nosso país. Eu queria partir dessa caracterização da pobreza e da desigualdade como dois traços fundantes, ou constitutivos, da nossa formação social. Assim teremos uma visão um pouco mais aprofundada e mais complexa acerca da relação entre pandemia e desigualdades.

O Brasil é um país profundamente desigual. E é desigual desde sempre. Um país que sempre conviveu com índices muito elevados de desigualdade, e essa é uma realidade conhecida por toda a literatura da história, das ciências sociais, da sociologia, do pensamento social brasileiro. Inclusive temos desenvolvido técnicas e metodologias inovadoras para abordar esse fenômeno tão duradouro. Eu tenho recomendado muito o livro recente do sociólogo Pedro Ferreira de Souza, chamado Uma história de desigualdade e a concentração de renda entre ricos no Brasil de 1926 a 2013. É um livro interessantíssimo. Ele vai tentar esmiuçar exatamente as dinâmicas e os mecanismos que fazem o processo de concentração de renda ser um fenômeno tão duradouro na história brasileira e, ao mesmo tempo, com uma capacidade grande de se renovar e de se adaptar. Mas o fato é que vivemos com a desigualdade há muito tempo, e temos a pobreza como um traço constitutivo do Brasil, que é um país, uma formação social, que convive com esses dois fenômenos há muito, muito tempo.

Talvez não seja necessário dizer que pobreza e a desigualdade não se confundem, não são a mesma coisa, são duas coisas distintas conceitual e empiricamente, mas são fenômenos muito fortemente relacionados. Os dois representam facetas muito cruéis

\footnotetext{
${ }^{2}$ Matéria publicada no portal de notícias G1, em 28/04/2020, mostrava os resultados de uma pesquisa que apontava que "Pretos têm 62\% mais chance de morrer por Covid-19 em São Paulo do que brancos". Disponível em: https:/g1.globo.com/sp/sao-paulo/noticia/2020/04/28/pretos-tem-62percent-maischance-de-morrer-por-covid-19-em-sao-paulo-do-que-brancos.ghtml. Acesso em: 21 jan. 2021.
} 
disso que a gente entende, de forma ampla, como injustiça social. Os seus índices são revelados de maneira particularmente impactante para nós brasileiros. ${ }^{3}$ Convivemos com isso há tanto tempo que é difícil o brasileiro se ver, se reconhecer, ter uma autorrepresentação ou autoimagem que seja completamente descolada dos fenômenos da pobreza e da desigualdade. É interessantíssimo, porque o tema da pobreza, por exemplo, incomoda a todos, sempre incomodou. Embora possamos elaborar a pobreza de maneiras muito diversas, do ponto de vista conceitual, narrativo, seja acadêmico ou não, mas o fato é que ela nunca deu origem a uma atitude ou a uma vontade política coletiva capaz de superar esse problema. Isso é um elemento curiosíssimo na história do Brasil: que nós convivamos com os altos índices de pobreza sem que isso se transforme de fato numa comoção nacional ou numa paralisação geral para que possamos reconstituir a formação social brasileira tendo esse como um dos elementos principais a serem superados.

Tem uma frase de uma socióloga, cujo trabalho sobre a pobreza eu admiro bastante, a professora Vera da Silva Telles, na tese sobre pobreza e cidadania no Brasil. ${ }^{4}$ Ela aponta uma coisa muito impactante. Ela mostra muitas coisas importantes sobre a relação entre o processo de construção da cidadania do brasileiro e a pobreza como um fenômeno duradouro. Diz, principalmente que a pobreza no Brasil foi se constituindo em uma paisagem, uma espécie de catástrofe sem autores. A pobreza vai se naturalizando no Brasil em vários sentidos, vai se tornando parte da paisagem, ela é parte da natureza, e vai se tornando parte da nossa cotidianidade, se naturalizando no nosso convívio diário. Convivemos com nossos colegas cidadãos tendo a pobreza como um pressuposto. Diriam os economistas, de forma tipicamente eufemística, que temos uma baixa intolerância aos altos índices de pobreza no Brasil. Significa dizer, na verdade, que nós nos comovemos muito pouco com o tanto de injustiça social que nós geramos neste país. Que geramos e sustentamos.

Se a pobreza pudesse ser definida exclusivamente como destituição material, já teríamos uma desgraça grande o suficiente. No entanto, sabemos - utilizando já o jargão

\footnotetext{
3 "Brasil é o nono país mais desigual do mundo, diz IBGE". Matéria publicada no jornal O Globo, em 12/11/2020. Disponível em: https://oglobo.globo.com/economia/brasil-nono-pais-mais-desigual-domundo-diz-ibge-24742041. Acesso em: 21 jan. 2021.

4 TELLES, Vera da Silva. Cidadania inexistente: incivilidade e pobreza; um estudo sobre trabalho e família na grande São Paulo. 1992. (Tese de Doutorado em Sociologia) — FFLCH, Universidade de São Paulo, São Paulo, 1992.
} 
sociológico - que ela não é só isso. Ela se revela também na própria constituição dos indivíduos e dos grupos sociais. Ela tem uma faceta política. É por isso que o tema da cidadania no Brasil dificilmente pode ser pensado sem ter a pobreza como um condicionante forte. $\mathrm{O}$ processo de constituição da cidadania — definido de maneira muito geral, como a condição de ser membro pleno de uma determinada comunidade abrangente, que seria a comunidade do Brasil, como um estado-nação — é completamente atravessado por esse tipo de iniquidade observável de maneira tão patente, tão dura e inescapável, que a gente não conseguiu constituir no Brasil, dada a enorme desigualdade, que é também uma desigualdade duradoura, e os altos índices de pobreza, a ideia que em alguns lugares foi mais ou menos sedimentada, que é a de um sentido de equivalência interclasses, vamos dizer assim. Uma certa constituição básica, de um sentido de igualdade fundamental entre as pessoas. Eu tenho cada vez mais a impressão, me dedicando a esse tipo de questão, que no Brasil, o sentido de igualdade básica é renegociado a cada novo conflito que ocorre. Não se tem algo ao qual recorrer, um princípio, por exemplo, segundo o qual se possa dizer: "no limite, todos temos os mesmo direitos". Sabemos que não temos. E boa parte dos motivos pelos quais não temos acesso aos mesmos recursos de justiça vem exatamente do fato de que temos na base disso tudo uma desigualdade abissal duradoura, já normalizada, e altos índices de pobreza que fazem com que, não uma minoria, mas a maioria numérica da população viva em condições muito precárias de existência.

Então já conseguimos ver, por exemplo, que a própria pobreza tem que ser vista como algo mais do que destituição material, o que não reduz a gravidade da injustiça material contida nesse fenômeno, mas a amplia e muito, se pensarmos em termos da tragédia humana, que é o que temos configurado aqui. Mas no final das contas, qual é a relação entre a pandemia, essa desigualdade tão antiga e essa pobreza tão duradoura?

Primeiramente, poderíamos pensar que a pandemia serviu como um fenômeno extraordinário, fora do normal, para revelar desigualdades já existentes. De fato, a pandemia funcionou para revelar uma série de desigualdades sobre as quais nem sempre tematizamos, que nem sempre aparecem nos noticiários, e que nem sempre incomodam. Incomodam muito pouco na maior parte dos casos. A pandemia virou uma espécie de lente de aumento porque todas as pessoas no mundo estão, inevitavelmente, olhando para os indicadores e tentando perceber a dinâmica com que o vírus se espalha, como incide, 
como provoca mortes e assim por diante. Inevitavelmente, acabamos comparando situações e conseguindo perceber uma série de desigualdades, iniquidades escancaradas no Brasil, exatamente pelo fato de que a pandemia revela as precaríssimas condições de parte da população para responder ao vírus, ou para se defender dele. Então estamos falando de condições muito precárias de moradia, saneamento, pavimentação de ruas e logradouros, que existem ao lado de ambientes altamente modernos, luxuosos. Há uma foto que mostra a fronteira entre o bairro do Morumbi e a comunidade de Paraisópolis. ${ }^{5}$ se não me engano, pois conheço pouco a geografia de São Paulo. Mostra aqueles prédios luxuosíssimos, com varandas tão exclusivas que nem sequer fazem sombra umas às outras, ao lado de Paraisópolis, que é uma favela enorme. Eu já vi pelo menos três capas de revistas falando sobre desigualdade no mundo tendo essa foto como ilustração. $\mathrm{O}$ Brasil é repleto dessas paisagens cruelmente contrastantes.

Então o primeiro tipo de relação que poderíamos elaborar seria essa: a pandemia serviu para revelar, para lançar luz sobre as nossas desigualdades já existentes. ${ }^{6}$ Em qualquer lugar do mundo em que o Brasil não projetasse ainda a imagem de um país muito desigual, com a pandemia, a cortina caiu rapidamente, o país aparece para o mundo como um país muito desigual também na situação de pandemia.

Mas podíamos pensar também, e é esse o caso, que a pandemia teria agravado desigualdades já existentes, não só reveladas, mas que ela incidiria também como uma variável adicional a ponto de tornar mais duras as condições sob as quais vive parte da população brasileira, na verdade, a maioria dela, inclusive criando novas desigualdades. Tudo isso é possível perceber no atual momento. Isso é interessante, e eu até tinha colecionado um conjunto de matérias sobre a questão, porém não tive tempo de elaborar de forma organizada para trazer hoje, ${ }^{7}$ mas é facilmente encontrável na internet, nos

5 A foto, captada pelo fotógrafo Tuca Vieira, pode ser conferida em: https:/gshow.globo.com/programas/conversa-com-bial/noticia/a-fronteira-entre-a-favela-de-paraisopolis -e-o-bairro-do-morumbi-gerou-uma-das-mais-impactantes-imagens-sobre-a-desigualdade-brasileira.ghtml. Acesso em: 22 jan. 2021.

${ }^{6}$ Matéria publicada no site do CLACSO, em 06/05/2020: "A pandemia expõe de forma escancarada a desigualdade social”. Disponível em: https://www.clacso.org/a-pandemia-expoe-de-forma-escancaradaa-desigualdade-social/. Acesso em: 21 jan. 2021.

${ }^{7}$ Nessa versão escrita da palestra, as referências e os links de acesso às matérias e aos textos coletados para ilustrar o argumento foram inseridos em notas de rodapé. 
grandes meios de circulação. E se quiserem ser mais específicos, dá para ir aos canais acadêmicos e institucionais que mostram ainda mais detalhes sobre o assunto.

Nesse contexto, os indicadores aparecem tentando mostrar que a pandemia, no Brasil, teve uma certa dinâmica, e começa a modificar e acentuar esses traços à medida em que, por exemplo, nos grandes centros urbanos, ela começa a se alastrar para as periferias, que normalmente são parte da composição urbana muito menos atendida por serviços públicos, com complicadores fortíssimos relacionados com a alta densidade demográfica, com as precárias condições de habitação, e aí se tem o vírus de fato se comportando de acordo com esse tipo de desigualdade ou traço de desigualdade.

Poderíamos utilizar um recurso que todo aluno de primeiro período de sociologia ou de ciências sociais aprende a usar, que é a imaginação sociológica, para tentar enxergar além dos índices com os quais temos contato diariamente. Somos inundados com esses índices e indicadores nos noticiários. Poderíamos pensar no que ultimamente se tem falado, por exemplo, acerca das condições de trabalho, dos tipos de hiper exploração dos trabalhadores de entrega por aplicativo, a exemplo do UberEats, Rappi, iFood, entre outros. Começou a surgir como parte das pesquisas das ciências humanas e sociais, uma série de dados acerca do grau de adoecimento dessa população, do grau de exposição que esses trabalhadores apresentam, que é muito desproporcional em relação a outras categorias de profissionais. ${ }^{8}$ Talvez o grau de exposição desses trabalhadores só rivalize com o dos profissionais da saúde que atuam diretamente na contenção do vírus. Como essas pessoas estão diretamente expostas cotidianamente, inclusive com vínculos e condições muito precárias de trabalho, vemos surgir os índices acerca do grau de adoecimento e taxas de mortalidade.

Vamos pensar numa situação hipotética, mas não distante da realidade, para tentar enxergar um pouco além desses índices, da frieza dos números divulgados. Imaginem que uma pessoa trabalhando com esse tipo de atividade seja responsável pela principal fonte de renda de uma família de três ou quatro pessoas. Ela não só está muito mais vulnerável do que a maior parte da população em termos de contaminação pelo vírus, como o seu adoecimento tem a potencialidade de multiplicar os efeitos. Imaginem que ela é o que se

\footnotetext{
${ }^{8}$ AQUINO, João Victor Maciel de Almeida; PILATE, Fabiano Diniz Queiroz; FÉLIX, Ynes da Silva. Uberização do trabalho e os riscos à saúde dos entregadores por aplicativo frente à pandemia da Covid-19. Revista Direitos, Trabalho e Política Social, v. 6, n. 11, p. 46-69, 2020. Disponível em: https://periodicoscientificos.ufmt.br/ojs/index.php/rdtps/article/view/10617. Acesso em: 13 abr. 2021.
} 
costuma chamar arrimo de família, sustenta uma família de três, quatro ou cinco pessoas. A interrupção do seu trabalho, já precário, o que não lhe permite acessar segurodesemprego, imediatamente deixa o entregador e sua família sem renda. No dia seguinte, são lançadas a uma situação de altíssima vulnerabilidade social, muitas vezes entrando na linha de extrema pobreza. Se essa situação se transforma em um impedimento permanente, significa que todo um grupo de pessoas entra indefinidamente nessa condição. Eu estou dizendo isso sem pensar em nenhum caso específico, mas qualquer um que tenha tido contato com o cotidiano das classes populares nas periferias urbanas no Brasil - eu faço parte desse grupo de pessoas que estuda o fenômeno — sabe que essa é uma cena extremamente comum. A gente consegue, com o olhar sociológico, imaginar situações que se transformam em hipóteses e que vão além daquilo que os números nos mostram no cotidiano.

Mas as ciências sociais também podem nos ajudar a enxergar mais longe. Não necessariamente no sentido linear, de adivinhar futuros, mas de perceber a situação presente dentro de uma perspectiva temporal mais alongada, e ver como esses dramas se comportam na longa duração. Nesse sentido, na intenção de esboçar um argumento sociológico acerca das relações entre pandemia e desigualdades, eu queria explorar o termo que está no título da palestra: "a pandemia e as nossas desigualdades duradouras". A expressão "desigualdade duradoura" vem de um estudo do sociólogo estadunidense chamado Charles Tilly, autor que influenciou toda uma geração de pesquisadores do campo da sociologia, em temáticas diversas, da ação social, da ação política, da ação coletiva, na sociologia política, e dos estudos sobre desigualdades sociais. Em 1998, ele lança um livro que se tornou muito influente, chamado Durable inequality, ${ }^{9}$ título que é traduzido por alguns como "desigualdade persistente". Eu estou traduzindo aqui livremente como desigualdade duradoura, para enfatizar o traço da nossa formação, pois somos desiguais desde sempre, e cada vez mais desiguais, sustentando índices cada vez mais elevados ou com baixíssima variação histórica no que se refere à pobreza. ${ }^{10}$

Por meio desse conceito, Tilly diz que na história da humanidade, as desigualdades mais persistentes, as que duram mais tempo e que são mais difíceis de

\footnotetext{
9 TILLY, Charles. Durable inequality. California: University of California Press, 1998.

10 Sobre o assunto, recomendo a seguinte coletânea: ARRETCHE, Marta (Ed). Trajetórias da desigualdade: como o Brasil mudou nos últimos 50 anos. São Paulo: Editora da Unesp, 2015.
} 
modificar, são aquelas que se estabelecem ao longo de categorias de classificação e hierarquização, como gênero, raça, etnicidade, sexualidade. Nesse sentido, a desigualdade de salário entre homens e mulheres é uma desigualdade duradoura na medida em que se relaciona a um tipo de categoria que de fato influencia a forma de distribuição de recursos, como dinheiro, poder, prestígio e assim por diante. Portanto, desigualdade duradoura é toda desigualdade que persiste ao longo das categorias que classificam e hierarquizam grupos e pessoas. A tese, defendida e demonstrada por ele no livro de 1998, passou a influenciar um conjunto crescente de autores e intelectuais que estudaram o fenômeno da desigualdade.

Eu gostaria de explorar aqui duas leituras recentes baseadas nas ideias de Charles Tilly, sobre o tema da desigualdade, e, talvez, com isso conclua a minha fala. Nesse ponto da nossa reflexão, já estamos muito além de uma leitura imediata dos dados que saem no jornal, tentando enxergar mecanismos mais profundos de manutenção das nossas desigualdades e da nossa relação com a pandemia. Nesse caminho, eu gostaria de propor e explorar a tese - espero chegar a isso no final — de que a forma como nós tratamos, vivenciamos, sendo pouco intolerantes com nossas desigualdades históricas, implica dificuldades muito grandes de lidar com a própria pandemia. Com isso, proponho que existe um paralelo acentuado entre a maneira como toleramos as nossas desigualdades e a forma como toleramos essa marca histórica e muito triste de cem mil mortes ${ }^{11}$ pela Coovid-19. Eu percebo uma relação muito forte entre essas duas coisas, mas eu gostaria de abordar esse tema das duas tolerâncias desenvolvendo algumas dessas ideias que partem de Charles Tilly.

Existe um trabalho muito interessante de uma socióloga da Universidade de Stanford, ${ }^{12}$ no qual ela utiliza o conceito (desigualdade persistente/duradoura) de Charles Tilly. A professora Cecilia Ridgeway elaborou o artigo: Por que o status importa para a desigualdade? E o que, exatamente ela está chamando de status no artigo? É aquela desigualdade que deriva de diferenças de prestígio e respeito. No linguajar sociológico,

11 Esse era o número de mortes na primeira quinzena do mês de agosto de 2020.

12 RIDGEWAY, Cecilia L. Why status matters for inequality. American Sociological Review, Bloomington, v. 79, n. 1, p. 1-16, 2014. Disponível em: https:/www.asanet.org/sites/default/ files/savvy/journals/ASR/Feb14ASRFeature.pdf. Acesso em: 02 mar. 2021. 
esse é um termo muito conhecido, faz parte do próprio vocabulário básico da sociologia. A forma como as pessoas e os grupos se diferenciam, não apenas em termos da quantidade de recursos materiais, de dinheiro, mas também em termos de quanto se tem de recurso de poder e de estima. Estima pensada como prestígio, reconhecimento. Ridgeway afirma que, seguindo de perto o que Charles Tilly propôs, também em suas pesquisas é possível perceber que as desigualdades mais persistentes são aquelas que se colam às nossas categorias de raça, gênero, sexualidade e outras.

Quando pensamos o "status" como gradiente de estima e prestígio, conseguimos perceber que o prestígio joga um papel importante na estruturação das desigualdades e da transformação de desigualdades de oportunidades em desigualdades duradouras, como Tilly as definiu. Ela argumenta que no nível macrossocial, as diferenças de status chegam a estabilizar desigualdades de poder e de recursos, transformando-as em códigos culturais acerca da superioridade ou inferioridade entre grupos e pessoas. Ou seja, emergindo dessas diferenças de status, desse tanto de estima que grupos de pessoas gozam, configuram-se crenças, códigos culturais que passam a contribuir para moldar a própria maneira como as pessoas se percebem e se classificam como mais ou menos capazes, como mais ou menos merecedoras de possuir recursos valorizados, como detentoras de mais ou menos recursos de poder.

Essas crenças, por sua vez, atuando já no nível micro, ou seja, no nível das relações interpessoais, funcionam como vieses culturais para formas de avaliação acerca do que sejam competências, habilidades, merecimentos e assim por diante. A autora vai estudar formas de contratação, e de que maneira esse tanto de status, o prestígio que deriva de vários outros processos, acaba funcionando como uma variável extra, condicionando a forma como as pessoas avaliam quem deve ou não ser contratado, quem deve ou não ter aumento, e assim por diante. Essa maneira de transformar prestígio existente em uma nova quantidade de oportunidades transforma as nossas diferenças por raça, gênero, sexualidade, estilos de vida baseados em diferença de classe em estruturas de distribuição de recursos. Com isso, temos o status se transformando em crença acerca de inferioridade ou superioridade, que se transforma em comportamento avaliativo e seletivo, que se transforma, portanto, em diferença de oportunidades (chances de contratação). É um estudo muito interessante que tenta mostrar algo que Tilly apresentou em termos 
numéricos numa longa duração histórica. Ridgeway demonstra como isso acontece no cotidiano de empresas, escolas e outras instituições formais.

Uma outra leitura bem interessante do conceito de Charles Tilly é feita pelo sociólogo brasileiro Sérgio Costa, intelectual e pesquisador que vive na Alemanha já há algum tempo, e que tem um trabalho sobre desigualdade bastante conhecido. Ele desenvolveu o conceito de "desigualdades entrelaçadas"13. Eu tive a oportunidade de discuti-lo pormenorizadamente recentemente na disciplina que ministrei na PósGraduação de Sociologia da UFPB. Sérgio Costa também aborda o conceito de Charles Tilly. Demonstra e revela a influência que o conceito tem no desenvolvimento de seu próprio trabalho, e afirma que recentemente os argumentos de Tilly têm sido aperfeiçoados, complexificados, na medida em que os pesquisadores estão buscando demonstrar que as categorias abrangentes, ao longo das quais as desigualdades se concretizam e se estabilizam, necessitam de categorias intermediárias que podem revelar outras diferenças importantes.

Tilly mostra que a desigualdade, no caso de um país com altas taxas de migração como Estados Unidos, ou certos países da Europa, a diferença entre migrante e nativo é enorme, altamente relevante para estabilizar a manutenção das desigualdades ao longo das gerações. Sergio Costa diz que é importantíssimo que percebamos variações nessa condição de migrante. Por exemplo, na condição de migrante em um país europeu, variam muito as suas chances de acesso a recursos e oportunidades, dependendo de onde você migra e em que época. Costa sustenta, entre outras coisas, que falar em desigualdade requer pelo menos que consideremos diferenças importantes em termos de: desigualdade de que, quando, onde e entre quem. Essas categorias que são válidas no estudo de Tilly permanecem sendo um insight central, seminal para esses estudos, mas é preciso refinar as ideias.

Costa sugere outra ideia interessante, que pode nos ajudar a pensar o Brasil. Quando vamos atrás dos mecanismos históricos, de renovação, de reinvenção das nossas formas históricas de desigualdades persistentes, ele diz que é possível pesarmos em

${ }^{13}$ COSTA, Sérgio. Desigualdades, interdependência e políticas sociais no Brasil. In: PIRES, Roberto Rocha Coelho (Org.). Implementando desigualdades: reprodução de desigualdades na implementação de políticas públicas. Brasília: IPEA. 2019, p. 53-77. Disponível em: https://www.ipea.gov.br/ portal/images/stories/PDFs/livros/livros/190612_implementando_desigualdades.pdf. Acesso em: 02 mar. 2021. 
"regimes de desigualdade". Estudando a América Latina, num grupo relativamente ampliado de pesquisadores abordando a realidade social na América Latina, eles conseguem mapear etapas históricas que caracterizam traços predominantes, ou traços mais persistentes na manutenção da desigualdade. Então é possível falar, por exemplo, no regime da escravidão até o século XIX, o nacionalismo racista, que vai do século XIX até as primeiras décadas do século XX, passando para um nacionalismo mestiço dos anos 1930 aos anos 1980, e depois a um regime multicultural, neoliberal, a partir dos anos 1980.

O importante de se perceber na ideia de "regimes de desigualdade", apontado por Sérgio Costa, é que a transição de um regime para outro nunca significa a completa destruição das formas passadas de desigualdades, mas revela a predominância de uma nova lógica. Então esse tipo de abordagem passa a ser muito importante, por exemplo, quando vamos estudar a forma como historicamente nos constituímos como uma sociedade tão desigual. É o caso da revalorização acadêmica por que tem passado o tema da escravidão no Brasil. Acertadamente o temos revisitado para podermos perceber em novos patamares o peso que têm o racismo e a discriminação racial no Brasil como formas de manutenção dos nossos padrões abissais de desigualdade social. No entanto, do ponto de vista sociológico, é importantíssimo trabalhos como esse de Sérgio Costa, pois o que se torna mais importante e desafiador para a sociologia não é tanto a tarefa de identificar continuidades entre o passado escravocrata do Brasil e as nossas formas presentes de desigualdades, mas, principalmente, compreender os mecanismos que fazem com que esse se torne um traço duradouro da nossa cultura política, da nossa economia, da nossa formação social de um modo geral. Perceber as lógicas predominantes ao longo do tempo, as suas mudanças e formas de permanência, de constância, de transformação, e como os elementos vão compondo essas formas de desigualdade passa a ser uma tarefa importantíssima para quem pretende compreender a fundo a persistência das desigualdades sociais no Brasil.

Tendo essas ideias em mente - e eu não tenho nenhum interesse em fechar uma aplicação direta ou uma conclusão precoce dessas reflexões que eu trouxe hoje, como parte do debate sociológico sobre desigualdades - , eu queria sintetizar um argumento, e com isso partir para concluir a minha fala: nós não só somos uma sociedade historicamente desigual, com pouquíssima variação nos índices históricos de pobreza, 
mas também somos um exemplo da durabilidade das formas categóricas de desigualdades, ou seja, das desigualdades que se estabelecem ao longo das linhas de raça, classe, gênero, sexualidade e outras.

Somos exemplos disso, e ainda temos um desafio, ao qual tenho me dedicado mais recentemente, o de enxergar essas coisas não como características separadas ou propriedades estanques da vida das pessoas em situação de vulnerabilidade social. Ou seja, uma condição de gênero não está completamente apartada de uma condição de raça, da condição de habilidade, de sexualidade. Essas categorias mais recentemente vêm sendo questionadas ou desafiadas pelo pensamento político do movimento feminista crítico, do movimento feminista negro, com o conceito de intersecção. A forma como essas categorias se combinam - e têm efeitos que só derivam da sua combinação torna a nossa análise acerca das desigualdades históricas ainda mais complexa. Significa dizer que não é suficiente adicionar aos nossos padrões históricos de desigualdade de classe elementos de raça; não basta adicionar às nossas desigualdades históricas de acesso a recurso material desigualdades de gênero; é necessário cada vez mais percebermos que a nossa desigualdade de recursos materiais, portanto a nossa desigualdade baseada em diferença de classe, é co-constitutiva das nossas diferenças de gênero, de raça, de sexualidade, e assim por diante. Esses elementos se constituem de forma recíproca e se reforçam mutuamente. É necessário compreender os seus efeitos combinados, o que é um desafio ainda maior.

Mas vamos chegar à tese que eu quero apresentar, na verdade uma hipótese. Não é uma tese porque eu não conseguiria defendê-la em toda a sua complexidade no tempo desta fala, mas gostaria de conversar com vocês a respeito. É um traço da nossa formação: convivermos com tamanha desigualdade, que tem efeito sobre a forma de nos constituirmos como cidadãos, portanto, tem efeito sobre nossos padrões de sociabilidade, sobre a forma como nos relacionamos uns com os outros, sobre a forma como resolvemos conflitos, inclusive através dos mecanismos jurídicos, a forma como acessamos e nos valemos da lei para resolver conflitos. Então a pobreza e a desigualdade atravessam toda a nossa formação social a partir de uma combinação muito intrincada de diferenças de gênero, de raça, de classe, de etnia e assim por diante. E já convivemos com isso há tanto tempo que me parece que a durabilidade, a persistência desse traço, juntamente com a dramaticidade dessa condição, promove entre nós uma tolerância absolutamente 
desumana com a nossa tragédia humana. A gente convive quase sem muito drama com tudo isso de trágico que tem na nossa formação e na nossa história.

Olhando por esse viés, não parece estranho, apesar de ser muito mais triste, que estejamos convivendo com um número crescente - uma tragédia inclusive anunciada por todos os especialistas — de mortes pela pandemia. Tendo o mundo como espelho, no sentido de que temos um mundo de exemplos de outras formas de agir em relação a essa pandemia, mas escolhemos um caminho que gerou, até agora, cem mil mortes. O mais grave, pelo menos para mim — esse é o meu depoimento — é a forma como temos naturalizado isso tudo. Já sabíamos disso - Simone é uma colega socióloga que está aqui talvez para confirmar - , que existiria uma pressão muito grande, que não é só exógena, não é só de fora, mas partiria também da nossa própria forma de sociabilidade, no sentido de normalizar essa tragédia. E hoje, com esse número absurdo de mortes pela covid-19, estamos de fato caminhando a passos larguíssimos no sentido de tornar normal essa tragédia.

Eu deixo para vocês estas duas figuras para serem comparadas. A forma como nós não estranhamos conviver com todas as iniquidades que formam o Brasil e o brasileiro, e a forma como estamos normalizando as mortes por covid-19. Eu acho que essa seria a minha contribuição hoje. Seria uma das maneiras como as ciências sociais podem tratar da relação entre pandemia e desigualdades. Eu faria esse paralelo entre a maneira como sempre convivemos relativamente tranquilos com a iniquidade social derivada dessa desigualdade abissal entre os grupos sociais, afinal somos um dos países mais desiguais do mundo, ${ }^{14}$ com índices de pobreza alarmantes, e a maneira como temos convivido essa é a outra figura - com um número crescente de mortes na pandemia, que parece não ter freio pela frente. Por enquanto, parece que só tem túnel; luz no fim eu não consigo enxergar para tão cedo. E temos normalizado isso. Temos normalizado, inclusive - e isto é interessante, caberia uma outra análise, talvez uma outra conversa - em formas de racionalização e justificação. Já existem narrativas se sedimentando acerca do porquê

\footnotetext{
14 “Com IDH quase estagnado, Brasil fica em $79^{\circ}$ lugar em ranking da ONU.” Matéria publicada pelo portal de notícias UOL, em 09/12/2019. Disponível em: https://noticias.uol.com.br/internacional/ultimasnoticias/2019/12/09/com-idh-quase-estagnado-brasil-fica-em-79-lugar-em-ranking-da-onu.htm?cmpid= copiaecola. Acesso em: 21 jan. 2021.
} 
devemos normalizar, ou até como temos que normalizar. Existem verdadeiras técnicas de como vamos conviver com esse absurdo.

Era isso o que eu queria apresentar hoje, como uma provocação ou uma forma de incentivar um debate sobre a relação entre a pandemia e as nossas desigualdades sociais. Eu quero agradecer a todo mundo, embora eu não tenha como saber exatamente quem está nos assistindo. Quero agradecer a todo mundo que se interessou e se deu ao trabalho de assistir. Fico à disposição agora para discutirmos essas ideias. Muito obrigado a Simone por ter aceitado ser mediadora, e muito obrigado a Nino por ter tido todo esse trabalho em todas as palestras que têm acontecido até agora como parte do Seminário. Eu estou à disposição para continuarmos conversando. Obrigado!

\section{Simone Brito:}

Rogério, obrigada. Queria dizer que gostei muito e, de fato, quando você fala que tem provocações, acho que são bem mais que provocações. Eu tinha visto o título e imaginado um caminho bem diferente. Imaginei que eram questões importantes, mas pensei que você faria apenas a discussão sobre como os elementos da desigualdade dramatizam a situação da pandemia. Mas você trouxe uma discussão que, em certo sentido, é bem mais urgente. Sua perspectiva é importante porque todo mundo se coloca, até com um espanto meio inocente, com ar de absurdo que não compreendemos, esse número do choque, cem mil mortes, e por que está tudo tão normal? Você nos faz pensar, com base em uma sociologia das desigualdades no Brasil, que já temos bem desenvolvido uma "frieza" com relação a muitas mortes. O fato mais chocante, tanto para o olhar dos não cientistas sociais quanto dos cientistas sociais, é essa naturalidade diante do fato de cem mil pessoas morrerem, e, pelo menos aqui em João Pessoa, nem máscaras as pessoas se preocuparem em usar. Existe uma coisa dessa normalidade que é muito doentia e, no senso comum, a gente tem a tendência de pensar exageradamente como se "as pessoas estivessem loucas". O teu argumento é interessante porque mostra que a nossa desigualdade, e, principalmente o traço estrutural da nossa tolerância com as desigualdades, e como todo o problema está colocado nessa tolerância ou frieza diante do sofrimento. Através da imaginação sociológica, você nos mostrou como a indiferença diante do número de mortes é nosso "natural", vamos dizer assim. Ou seja, tolerar cem mil mortos e seguir com a vida normal já era de se esperar dessa nossa trajetória de 
conviver com a alta tolerância à desigualdade, de estarmos acostumados a esses mecanismos. E isso, praticamente, torna a indiferença um traço nosso.

Daí, muitas coisas se iluminam. vêm muitas ideias. Uma fala consegue atingir o ponto ideal justamente quando traz várias questões para pensarmos. Uma delas, obviamente, é esse traço, essa naturalização e os tantos outros mecanismos de produção da indiferença que estão ligados a ele. Podemos pensar na quantidade de mecanismos que existem para manter isso, para fazer com que nossa tolerância ao sofrimento seja tão alta. Pensei numa discussão que se tornou muito evidente agora na pandemia, mas que também poderia ser feita de forma geral: o papel do Estado, como ele atua, ou como houve tanta gente trabalhando para que essa nossa tolerância e para que essa desigualdade permanecesse. É uma pergunta simples e ao mesmo tempo importante. Tantos anos de políticas públicas para o combate à desigualdade, isso sempre foi um mote, e, no entanto, ela só se aprofunda. Como é que a gente lida com isso? Acho que não é preciso ser muito foucaultiano para começar a desconfiar que, na verdade, essas políticas estão trabalhando para o aprofundamento das desigualdades.

Outra questão — ligada à minha área de estudo — é saber como isso está relacionado ao elemento das nossas sensibilidades, uma sensibilidade particular que nos organiza: que aceita e normaliza as condições de vulnerabilidade, a pobreza, a desigualdade. Temos uma grande tolerância ao sofrimento do outro - claro, um outro de cor e classe específicas. É preciso pensar como as sensibilidades são manipuladas o tempo inteiro para que esse estado permaneça. Lembrei de várias coisas quando você estava falando, especialmente das filas para o auxílio [emergencial], que foram noticiadas como um fato normal da burocracia, esquecendo que muitas pessoas tiveram que ficar em filas sob o risco de contaminação, além das fraudes de pessoas de classe média e alta que receberam o auxílio. Essa sensibilidade, melhor: insensibilidade, está presente no nosso cotidiano e, para o olhar não treinado pela sociologia ou pelas ciência sociais, todos os dias temos muitas rotinas que buscam dar o verniz de normalidade à crueldade sistemática.

Tem gente que diz "e daí?" se morreram cem mil. A sua fala nos leva a entender como a normalização é um elemento sistemático e organizado. Daí, podemos pensar essa organização em vários níveis e com vários efeitos. 
Não tenho, portanto, uma questão. Queria apenas chamar a atenção para esse aspecto da sua argumentação que toca no cerne dos nossos problema. Não é só uma aceitação dos cem mil casos! Podemos concluir que estaremos dispostos a aceitar muito mais! Vamos seguir com a normalização da tragédia como aconteceu várias outras vezes. Eu teria outros comentários, mas prefiro ler algumas perguntas.

\section{Rogério Medeiros:}

Antes das perguntas, me deixe comentar seu comentário, porque ele é muito bom. Eu gosto muito disso que você chamou atenção relacionado com a pandemia, e relacionado com a forma como nos relacionamos com nossa desigualdade, essa história da uma economia das sensibilidades. Você tem toda razão. Você vê que o campo de estudos sobre políticas sociais já lida com a potencialidade que as políticas sociais têm de gerar estigma. Como uma política social pode ser estigmatizante, como ela se transforma em um mecanismo de desrespeito. Como ela pode se transformar numa injúria moral esse é o seu campo, sua área. Só num lugar onde a gente naturaliza a pobreza em um grau tão elevado, para não se achar um escândalo as filas, por exemplo, para pagamento do auxílio emergencial em plena pandemia, sob um regime que recomenda, senão o governo, a condição geral, o isolamento. É uma coisa escandalosa, é um desrespeito num grau absurdamente elevado, e, no entanto, entra na roda da normalização. Eu diria que se levarmos muito a sério aquela frase que eu citei sem ler, de Veras Telles, de que na verdade a pobreza se faz natureza no Brasil, ela é parte da paisagem, algo que damos por certo, então acaba que nós estabelecemos uma relação, se a gente falar em sensibilidade, de normalidade, de fatalidade, eu diria até que a pobreza acontece, ela está aí. As mortes, a desgraça, elas estão aí. Ela é simplesmente um elemento adicional nessa condição de estar em filas quilométricas para buscar algo, para conseguir sobreviver numa situação tão arriscada.

Há um paralelo muito forte, me parece. Pelo menos essa é a minha primeira impressão, entre a maneira como não reagimos a essas tantas tragédias duradouras e persistentes e essa nova tragédia por nós normalizada.

Uma coisa que eu não explorei, e eu trouxe para explorar, mas fica como um dos desdobramentos disso que eu pretendo falar depois de maneira mais detida. Essa maneira de usar a ideia de Charles Tilly em termos de status, por exemplo, abre uma questão muito 
interessante para pensarmos em situações que ocorrem hoje no Brasil. Por exemplo, temos discutido, ou pelo menos uma parte do espectro político brasileiro tem discutido, de que a atitude de governantes, do presidente da república, ministros e tudo o mais, de desacreditar temas, pessoas, grupos, situações, riscos, tratamentos, funciona exclusivamente como uma espécie de guerra semântica. No entanto, numa perspectiva dessa, como nessa situação, por exemplo, a gente falar que o status opera um tipo de lógica que pode ser independente de outras lógicas já conhecidas na manutenção das desigualdades, podemos pensar a autoridade máxima, a política máxima no país, desdenhando de traços que configuram grupos, é por definição, quase que uma exemplificação de uma retirada brusca de reconhecimento, ou seja, é um assalto ao prestígio, vamos dizer assim. Você toma de assalto aquilo que você poderia supor que um grupo tem de prestígio, e você anula esse prestígio, e esse grupo está, no debate público, na disputa pública por recursos, fragilizado automaticamente. Não tem como ser diferente, porque você tem alguém investido de autoridade dizendo que esse grupo não tem essa estima toda, a ponto de ser permitido ou aceito que ele sofra essa, e essa, e essa violência com esse tipo de descumprimento de direito e tal e tal. Esse é um caminho para seguirmos discutindo. A forma como as coisas acontecem, como efetivamente ajudam e interferem no jogo político inteiro. Sigamos com o debate.

\section{Simone Brito:}

Só mais um comentário. Também há um elemento ainda mais complexo para pensarmos sobre esse tipo de atitude das autoridades hoje. Temos uma sociedade acostumada à desigualdade. Uma parte dela, ao menos, aceita o que está acontecendo. Acha normal. Então nosso problema é que isso, que num certo sentido é aberrante, fora da ordem de uma vida decente, uma quebra de civilidade, ganhou um status de normalidade. Infelizmente, não se trata de um momento desviante da nossa história. Vamos pensar em políticas de sinceridade, e dizer exatamente como é inaceitável e, ao mesmo tempo, comum e regular o que a gente está vivendo.

Vamos às questões que foram aparecendo no chat. Acho que algumas já foram tratadas, mas eu vou fazer dois blocos mesmo assim.

Sebastião perguntou por que as desigualdades são duradouras e persistentes. Elas são próprias dos países periféricos e com nível de civilidade baixo? 
Nino diz que gostaria que você falasse um pouco sobre esse ódio que as elites econômicas brasileiras têm pelas populações tradicionais e seus costumes.

E uma terceira, Larissa Brasil diz que essa tolerância com relação à desigualdade é um pressuposto da desigualdade duradoura.

\section{Rogério Medeiros:}

Por que as desigualdades são persistentes e duradouras? Essa é uma pergunta nada fácil. E na outra parte, se elas são características dos países em desenvolvimento, de baixo IDH?

Bom, para começar, eu diria que quando você toma os bons estudos sobre desigualdade - quando eu digo bons estudos, são estudos que acabaram influenciando de forma decisiva os caminhos da pesquisa no campo da desigualdade - é muito difícil identificar uma causa para a persistência das desigualdades ou até mesmo uma lógica única. Por exemplo, o livro que eu citei antes — não sei se você já estava, Sebastião — quando eu recomendei o livro de Pedro Ferreira de Souza, um pesquisador do IPEA (Instituto de Pesquisa Econômica Aplicada), derivado da sua tese de doutorado em sociologia, chamado Uma história da desigualdade.

O livro é interessantíssimo, ele trata do fenômeno da concentração de renda entre os ricos no Brasil em um período bem longo. Na verdade, eu acho que é um dos estudos com período histórico mais longo no Brasil, com uma metodologia também inovadora. Por exemplo, é um tipo de metodologia que já leva em consideração dados de imposto de renda, que é algo que o Thomas Piketty vem fazendo em termos comparativos. E uma coisa que de cara está colocada no livro é que não existe uma lógica única, nem mesmo como tendência, na manutenção da desigualdade no Brasil. Se você tomar, por exemplo, a relação entre desigualdade e crescimento, ela varia ao longo da história brasileira, a forma com mais crescimento significou redução ou aumento da desigualdade e esse tipo de coisa. Têm vários processos, e no final das contas, a maneira como metodologicamente ele lida com isso é separando em períodos históricos. De fato, eu acho sábio fazer isso, quer dizer, assentar fortemente no contexto histórico para tentar explicar esses ciclos, mas tem um dado que ele consegue perceber, e que na verdade não é só dele, está presente 
como parte dos estudos sobre desigualdade, que é uma relação muito forte entre democracia e desigualdades.

Essa relação é algo ainda a ser destrinchado nos detalhes, mas no geral a fórmula é essa: "mais democracia, mais igualdade"; ainda que tenhamos países que são democráticos e altamente desiguais, ou países que sejam autoritários, com regimes autoritários, com mais igualdade, o que é possível, mas as políticas que tendem a ser adotadas no sentido de minimizar a desigualdade e seus efeitos, por exemplo, a pobreza, são tomadas dentro de contextos democráticos adensados, ou renovados, ou revigorados. Esse é um ponto.

Então não temos uma resposta única. Mas o interessante no estudo que eu trouxe para falar disso, o estudo de Charles Tilly, no qual a sua preocupação central é como, a partir de que caminhos, ou qual é a dinâmica que faz com que desigualdades passadas se transformem em desigualdades presentes, é que as desigualdades mais duradouras, mais persistentes, mais difíceis de mudar têm relação com traços que são próprios, não necessariamente da economia, mas do próprio mundo da cultura, a forma como as pessoas se concebem como superiores, inferiores, diferentes, mais aptas e menos aptas, são as categorias que formam identidades e diferenças entre grupos.

Esse processo que os sociólogos da cultura conhecem bem, que é o fechamento de grupo, a maneira como um grupo constrói as suas fronteiras, como se relacionam e concebem os outros, a forma como eles elaboram o sentido de serem superiores ou inferiores aos outros, como isso impacta o seu acesso a recursos: esse é o grande achado de Tilly. Se a gente pudesse pensar, por exemplo, se todas as consequências sociais de desigualdades econômicas fossem facilmente dedutíveis, então, na medida em que tivéssemos um mecanismo econômico para equalizar a distribuição de bens, teríamos, necessariamente uma equalização nas relações, nas formas de sociabilidades. Ele afirmou que não só não é assim como as formas econômicas mais duradouras de desigualdades são aquelas que se estabelecem e se enraízam em categorias que são categorias culturais, como categorias de raça, de gênero, de sexualidade, entre outras. $\mathrm{Na}$ verdade, esse argumento pode não responder a certos problemas específicos, mas abre perspectivas muito amplas. Eu explorei só duas aqui, dois autores que fizeram uso da ideia para explorar elementos sobre como traços culturais se transformam em estruturas de desigualdade. 
Isso é característico das sociedades em desenvolvimento, emergentes? Não, não é. Você pega países como os Estados Unidos, e a forma como as desigualdades raciais foram se construindo através de processos que são específicos para a história americana, e outros que são compartilhados com outros países. Por exemplo, se vínhamos falando sobre a escravidão como um fenômeno histórico, e como ela tem efeito no processo de constituição das nações - a experiência de terem sido colônia, como abordam os estudos coloniais, pós-coloniais e a perspectiva decolonial - mostram que esses traços não são, necessariamente, exclusivos dos países periféricos. Não é a situação, vamos dizer, a posição geopolítica ou socioeconômica atual que determina que suas desigualdades sejam ou não duradouras, que se estabelecem ou não ao longo das categorias culturais. Isso é uma coisa que aparece em diferentes países e diferentes lugares, através de traços que são compartilhados, que permitem comparação, e outros que são únicos, que são próprios da sua trajetória singular.

Nino comenta sobre o ódio das elites. Já que não é uma pergunta, vou me dar ao luxo de não responder, mas comentar também. É outra coisa que parece ter ficado muito evidente atualmente. Primeiro, é interessante e importante que quando se fale de elites, se classifique bem esses grupos. Por exemplo, têm sociólogos brasileiros que vêm estudando o posicionamento das elites, e eles cuidaram de ver variações, digamos, em frações dessa elite. De fato, a gente tem um tipo de coisa, um fenômeno que parece ter ficado muito evidente nesses últimos meses, que se quisermos colocar de maneira bem eufemística, a gente diria assim: parece uma indisposição crônica [das elites brasileiras] de jogar a favor da maioria. Estamos falando exatamente das pessoas que fazem as regras do jogo, que determinam o destino da partida, e parecem ter uma indisposição crônica de pensar na maior parte das pessoas. Isso, dito dessa forma, não nos permite perceber como ódio, mas quando a gente considera os depoimentos e como é que essa coisa se concretiza em discursos, em narrativas, a gente consegue perceber o ressentimento, ódio, medo, e um monte de coisa envolvida nessa maneira como as elites reagem ou lidam com as classes subalternas deste país. Isso também não é uma coisa nova. Se todo estudo parte de uma hipótese, um pressuposto, se eu fosse fazer um estudo sobre elites, eu dificilmente elegeria como hipótese ou como cenário hipotético inicial a ideia de que a pandemia criou esse ódio; não é assim de forma alguma. Me parece que a situação atual colocou novos fatores para que essa disposição — vamos colocar em termos sociológicos mais modernos 
— se tornou mais patente, mais evidente, se concretizou em comportamento de maneira muito mais escancarada.

Eu me lembro, só para falar um pouco sobre a peculiaridade do posicionamento das elites, de um estudo já bastante conhecido, que é o estudo da Elisa Reis, socióloga da UFRJ, sobre elites no Brasil. No final da década de 1990, publicou um artigo - o estudo é bem maior que esse artigo - que eu cheguei a trabalhar numa das disciplinas do PPGS. Tratava do posicionamento das elites em relação ao problema da pobreza e da desigualdade. ${ }^{15}$ Ela distingue entre elite econômica, política, sindical, e aí segue um monte de tipos de elites; ela faz entrevistas, faz questionários bastante numerosos. Interessante quando você toma ali o final da década de 1990, a educação e a desigualdade apareciam como dois principais problemas do Brasil para as elites.

É interessantíssimo, a elite consegue identificar que a situação da educação no Brasil é um problema, é um dos principais, e a desigualdade também. Até aí, você pensaria, puxa vida, temos uma elite que parece ter uma consciência, mas quando você parte para perguntar, e disso são feitas as boas pesquisas - de boas perguntas - , quando você passa para esmiuçar esses dados, de quais seriam as soluções, como que a gente pode passar por isso, a quem cabe resolver esses problemas, é quando você vê, de fato, se concretizando um tipo de atitude que agora se pode ver refletido nos comportamentos que você considera, por exemplo, como ódio das elites, ódio aos pobres.

É muito patente naquela época que a elite percebia a educação como sendo um dos problemas, mas concebia um ideal de educação que separasse claramente uma educação provida pelo estado para aqueles que não podem pagar — de pior qualidade — de uma educação para quem pode pagar. Então a educação é um problema, mas que pode e deve ser resolvido, desde que não se mexa nos privilégios de classe. E mais, a educação é um problema, e quem deve resolver o problema da educação é o Estado. Até porque para os membros das elites não existem problemas com a educação deles, segundo a maneira como se concebeu o problema pela elite. E aí têm vários outros desdobramentos disso, tem comparação com elites de outros países, uns muito mais desiguais ou mais pobres que o Brasil. Tem uma comparação com as elites de Bangladesh, com de outros

\footnotetext{
${ }^{15}$ REIS, Elisa P. Percepções da elite sobre pobreza e desigualdade. Revista Brasileira de Ciências Sociais, São Paulo, v. 15, n. 42, p. 143-152, 2000.
} 
lugares, é bem interessante. Mas só para a gente pensar como esse ódio das elites é uma coisa complexa, refinada, e num certo sentido, perversa. Ela é perversa no sentido de que tem um refinamento, tem uma complexidade nessa elaboração, não é um simples dar de ombros para o que acontece, tem um posicionamento ativo.

Larissa pergunta se a tolerância à desigualdade é um pressuposto. Essa é uma pergunta difícil de responder. Na minha fala, eu até aventei uma hipótese. Eu acredito que a permanência desse traço de forma quase inalterada na história do Brasil reforça o próprio traço. O que quero dizer com isso? Tenho a impressão de que a manutenção de índices muito elevados de desigualdade no Brasil é parte da configuração da nossa tolerância à desigualdade. Se vivêssemos, talvez, períodos prolongados de muita desigualdade alternados com períodos de pouca desigualdade, por hipótese, talvez a gente tivesse acostumado tanto à existência da desigualdade, mas tivesse também uma geração acostumada com a não existência de graus tão altos de desigualdade, e teríamos de fato um conflito toda as vezes que ela chegasse a níveis muito altos. Então a gente tem de fato uma tolerância à desigualdade num cenário que não mudou muito ao longo do tempo, até para concebermos como seria uma outra situação. Nos tornaríamos menos tolerantes à desigualdade caso as condições socioeconômicas mudassem muito fortemente, caso nos tornássemos muito mais iguais? Talvez.

É um caminho, um campo que tem estudado isso de maneira muito interessante, de maneira muito complexa e refinada, são as pessoas que estão particularmente interessadas em saber o que leva a população a apoiar ou a não apoiar, legitimar ou deslegitimar as ações do governo, as ações do Estado, no sentido de mais desigualdade ou menos desigualdade. Ou seja, quais são os pressupostos de uma população que legitima ou deslegitima políticas redistributivas, por exemplo? Esses estudos estão muito preocupados com isso. De que forma o gradiente de desigualdades e sua permanência afeta ou não as escolhas e decisões por políticas distributivas? O quanto a democracia está consolidada e afeta ou não a forma como a população apoia medidas distributivas? É um caminho a ser explorado, é um caminho que a sociologia também já vem explorando. Essa é a minha resposta, um pouco “saída pela tangente”. Não há agora uma resposta fácil para sua pergunta. Uma pergunta boa e bem difícil de responder. 


\section{Simone Brito:}

Rogério, obrigada. Temos mais algumas questões.

Anderson quer saber como você observa o discurso de naturalização das mortes nos estratos sociais mais baixos.

Ana Beatriz diz: "com a naturalização das mortes, os poucos impactos sobre as desigualdades sociais e as ações individuais, existe alguma explicação para tão pouca empatia pelo próximo?"

Nubia Guedes pede que você faça um link da banalização das mortes com a biopolítica e a necropolítica. Como a estatística coisifica essas mortes?

\section{Rogério Medeiros:}

Obrigado pelas perguntas.

Como explicar naturalização das mortes pelos pobres?

Veja, se existe uma naturalização da pobreza e das desigualdades, ela não é uma naturalização que aconteça só no topo da pirâmide, a sociedade naturaliza a pobreza, desigualdade, miséria, tanto quanto naturaliza as mortes de alto a baixo, certo? Não existe algo como uma diferença..., pelo menos vou colocar aqui como hipótese, pois eu não teria dados disponíveis para mostrar para vocês, até também porque não coletei estudos sobre esse elemento para trazer para a palestra. Mas não existiria algo como uma visão alternativa acerca das mortes advindas de um estrato da população mais afetada. É difícil de se levantar isso como hipótese. A sociedade inteira acreditando e agindo como se tudo isso fosse parte da natureza, que é uma grande tragédia sem autores, que isso tudo é assim mesmo. Por que os pobres fariam diferente? Por que a população mais afetada faria diferente?

A pergunta que você faz em relação às mortes causadas pela Covid, é a pergunta que eu posso fazer em relação à pobreza, à fome, à miséria. Por que haveríamos de supor que a população mais afetada por esse estado de coisas fosse aquela capaz de elaborar a visão mais crítica sobre esse estado de coisas? Isso não é impossível, de fato, e a gente, talvez de maneira rápida, possa pensar ou esperar que fosse diferente. Mas eu não vejo como uma contradição.

O Brasil como coletividade naturaliza suas misérias. E naturaliza também essa tragédia. Agora, muito mais difícil é saber quais são os mecanismos que operam aqui. 
São vários, e a sociologia só consegue tratar disso fatiando o problema. Ora, estamos falando, por exemplo, de como é que as ações do governo compõem uma certa economia das sensibilidades, como se discutiu com Simone. Ora, estamos falando em como é que o posicionamento de pessoas com autoridade agindo e fazendo, retiram reconhecimento e com isso afeta a distribuição de prestígio que pode se concretizar em estruturas de desigualdades, e assim por diante. Têm vários mecanismos, uma quantidade muito grande de fatores que pode gerar o que percebemos na sua face mais visível e que, a princípio, eu concordo com a Simone, e podemos pensar que parece pura loucura ou irresponsabilidade o fato de que as pessoas não estão dando a mínima importância para cem mil mortes. Mas é absolutamente normal nessa sociedade fazer pouco de uma tragédia desse tamanho. Essa é, pelo menos, a hipótese que estou trazendo, isso não é só por parte das classes menos afetadas, as elites, envolve a sociedade inteira.

\section{Simone Brito:}

Rogério, posso fazer um comentário de uma coisa que lembrei? Em Cem anos de solidão há uma passagem muito forte: o dia em que o os trabalhadores da empresa que exporta bananas resolvem fazer uma greve. Os americanos, donos da empresa, não aceitam a negociação, trazem um grupo e metralham todos os trabalhadores. São centenas e centenas de trabalhadores mortos, um campo tomado de corpos. Gabriel García Márquez descreve o chão coberto de pessoas mortas, e durante a noite, alguém limpa, tira aquelas pessoas de lá, cada um vai para seus velórios, e no outro dia ninguém lembra do que aconteceu. Todo mundo está andando pela praça e alguém pergunta: "mas e os trabalhadores?" Que trabalhadores? Que mortes? Essa cena me marcou muito, e muitos anos depois, conversei com um colega colombiano e a gente estava falando de García Márquez, falando do realismo fantástico, esse termo extremamente problemático, da imaginação - obviamente ele tem uma grande imaginação -, mas eu inclúi isso na imaginação do García Marquez, e esse amigo disse: "não, não, mas isso não foi imaginação, isso aconteceu mesmo, todo mundo sabe que isso aconteceu. E centenas foram mortos, não houve processo, não houve nada, e ninguém mais fala sobre esse assunto".

Então tem um elemento da nossa condição: de dependência, de explorados, de pessoas que não receberão justiça. Só queria chamar atenção como essa cena está ligada 
a isso que estamos vivendo com esse número de mortes absurdo. A gente não tem "teto" de mortes, não existe um teto que vai nos levar a dizer: chega! Digo isso porque se cem mil ainda não é esse número que não envergonha profundamente a todos, a gente não tem limite. E, muito provavelmente, com o andar da carruagem, isso nem vai ser um elemento que paute, de fato, debates, porque as mortes vão ser vividas por dores individuais de cada família, cada um vai lidar com seus lutos.

Trazer essas mortes para um debate político sobre a desigualdade será, talvez, um dos processos mais difíceis porque, como você falou, todo esse motor processual de normalização da indiferença vem atuando há muitos anos. Talvez a nossa tecnologia mais sofisticada seja a de encobrir as desigualdades, por isso elas não voltam como temática, como um elemento central para a gente discutir. Atualmente, está tendo uma discussão sobre taxação, impostos. Mas como vai ser feita? Quem é que vai ser considerado rico ou muito rico? Há esse elemento tão problemático, ou seja, os riscos dos quais você falou, há os processos de apagar de fato essa discussão, e quando ela é feita, se torna reificada. As pessoas não têm uma noção clara do que é a desigualdade, de como se reproduz e de como cada um faz parte desse processo.

\section{Rogério Medeiros:}

É isso mesmo. Esse negócio de Cem anos de solidão é impactante demais. Simone, eu concordo. Tem algo disso que você chamou atenção de modo muito preciso. Bom, eu falei sobre isso, mas a tendência, e aí talvez seja uma maneira mais qualificada de responder à pergunta que o Anderson tinha feito sobre a naturalização das mortes pelos pobres, como explicar, e tudo o mais. É isso que você estava falando sobre a tendência. Veja, hoje eu vi uma estatística, se não me engano é da Johns Hopkins, que é quem tem feito a maior parte das previsões, e assim, o cenário para o Brasil é atingir em novembro de 2020 cento e noventa e tantos mil mortes. O mais gritante do gráfico mostrado é que até dezembro, com cento e noventa e tantas mortes, nem de longe ainda é o pico, é uma curva inclinada ainda. Então a gente está no meio de uma tragédia, chegamos a cem mil e estamos subindo. Uma coisa muito grave.

Acho que você foi precisa ao dizer que as mortes tendem a ser tratadas como pequenas tragédias familiares, mais um paralelo importante com a pobreza. Um desdobramento dessa ideia, a pobreza como algo mais do que só distribuição material, é 
uma pobreza que impede a criação ou a sedimentação de um sentido mais efetivo de cidadania, que a gente vinha falando quando citei a Vera Telles. Traz o traço tão fácil de reconhecer entre as questões que mais afligem os pobres no Brasil - a grande parte da população — de tratar necessariamente a sua situação como sendo uma situação individual, ou seja, no registro da individualidade. Por isso que faz tanto sentido você pensar na elaboração de quem vive numa situação de pobreza, elaborar o sentido de dignidade como sendo todo relacionado ao mundo doméstico. É o sentido da casa em ordem, da família em ordem ou da honestidade pessoal que se prova como "sou pobre, mas honesto". Quer dizer, isso é um dos efeitos mais deletérios, um dos efeitos mais nefastos dessa dificuldade de consolidar um sentido de cidadania centrado na ideia de direitos.

O problema não é visto como uma questão coletiva, a ser tratada coletivamente, por políticas públicas a serem bancadas por um esforço coletivo, fiscal, que se estabeleça em cima de instituições, que sejam responsáveis por mitigar um problema, que é visto como de responsabilidade de todos. Trata-se de desdobramentos do pressuposto de um Estado que deve dar conta de um mínimo de condições para que todos sejam considerados e tratados como membros plenos, ou seja, como cidadãos. No entanto, no lugar disso temos um tipo de desigualdade, um tipo de pobreza tão abjeta, que torna tudo isso algo muito distante.

Temos um grande contingente da população que nunca se viu como pessoas detentoras de direito, que não elabora os seus problemas como problemas coletivos, são pequenos dramas individuais. E a gente pode ver um paralelo com a forma de tratar a morte por Covid, o adoecimento e tudo mais, como pequenas tragédias individuais e nunca elaboradas como parte de algo a ser remediado coletivamente, a ser tratado por políticas públicas e assim por diante. Bom, temos um governo, para ser sincero, que em vez de gerar políticas, gera gincana, como concurso de melhor máscara. O que esperar? Cem mil mortes é algo que não pode ser concebido como fenômeno individual em nenhum parâmetro imaginável. O número se impõe, se morreram cem mil pessoas dentro desse limite geográfico, então o problema é coletivo pelo número, o número se impõe, não tem como conceber de outra forma. E um representante máximo do Estado, um ministro, vai propor como principal política da sua pasta um concurso para a máscara 
mais criativa. ${ }^{16}$ Como é que que você vai tratar isso como uma questão coletiva? Vai ser tratado como se fossem pequenas tragédias individuais.

Acho que Ana Beatriz perguntou sobre a empatia. É um pouco disso que eu estava falando desde o início. Parece que o brasileiro não está se escandalizando com o tamanho da tragédia, e nós olhamos pela janela e vemos tanta gente lidando com a vida como se nada estivesse acontecendo. A discussão que eu propus para hoje era perceber isso não como uma exceção, mas como um traço da nossa maneira de lidar com nossos problemas mais graves. Estamos diante de um problema muito grave, e a gente está lidando da mesma forma como se lida com a pobreza e com a desigualdade, é esse meu argumento.

A pergunta da Núbia é uma pergunta grande, mas é bem direcionada. Pergunta sobre a relação entre a banalização das mortes, biopolítica e necropolítica, e como de fato as estatísticas funcionariam para coisificar essas mortes.

Tratei indiretamente no papel dos números no início da minha fala, mas é interessante tratar da maneira que você está propondo. O que seria, pelo menos para falar disso para pessoas que não conhecem esses termos ou não estejam familiarizadas com o linguajar desse tipo de tradição, digamos, da análise sociológica que vem dos trabalhos do filósofo Michel Foucault.

A ideia da biopolítica, que é exatamente essa forma como aquilo que nós entendemos como governo, como instituições de governo, como o Estado, vão se constituindo a partir de tecnologias específicas que não só são modos de fazer, mas também constituem sujeitos, constituem pessoas e a constituição de governos, ou seja, o aperfeiçoamento e a crescente abrangência das tecnologias de governo vão transformando, digamos, isso que a gente percebe como uma macroestrutura, que é o Estado, como sendo um grande complexo de tecnologias para lidar com populações. São políticas que ditam o que a vida vai ser: quem deve morrer e quem deve viver, quem pode morrer e quem deve ser preservado, são políticas exemplos de biopolítica.

O conceito de necropolítica, que é um conceito que vem sendo muito discutido atualmente nos debates da filosofia política, da sociologia política, é proposto como um

\footnotetext{
${ }^{16}$ Ministério faz concurso de máscaras e prêmio é tarde com Damares e Michelle. Uol Notícias. Disponível em: https://noticias.uol.com.br/politica/ultimas-noticias/2020/05/20/concurso-mascara-crianca-premiodia-com-damares-e-michelle-bolsonaro.htm. Acesso em: 22 jan. 20121.
} 
desdobramento do conceito foucaultiano, pelo filósofo camaronês Achille Mbembe. Os textos dele, inclusive, já foram traduzidos para o português, e o conceito de necropolítica vem daí. Se a biopolítica, para Foucault, significava as tecnologias de governo das populações e da vida, a necropolitica é a biopolítica no sentido de produzir mortes, são tecnologias não só de gerir, mas de dar direcionamento, não só à vida, mas também à morte. Não é só quem pode viver e quem pode ser deixado ao risco de morrer, mas é quem deve morrer. De que forma e pelas mãos de quem? O quanto aceitamos que se morra? Quem a gente aceita que morra? Quem a gente não aceita? De que forma o Estado atua no sentido de agravar os riscos de morte?

Então, exemplos de políticas de morte no Brasil de hoje podem ser visto claramente. Cito o caso em que um governador é capaz de subir em um helicóptero e, junto com os policiais, atirar para baixo numa área, só porque ela é considerada um local violento, onde vivem bandidos. E a câmera filma tiros sendo disparados, aparecendo como uma chuva em cima de uma região de favela. E depois você fica sabendo que morreram crianças na saída de escolas e tudo mais, e isso também se normaliza no cotidiano. Afinal de contas, aquela é uma região de pessoas perigosas, e atirar a esmo parece ser justificável que o Estado o faça, e que o governador propagandeie, o faz parecer normal, e assim por adiante. Temos vários outros exemplos da necropolítica no Brasil, como decidir deliberadamente não usar os recursos disponíveis para salvar vidas, é uma forma de promover mortes também, é um tipo de necropolítica. Desacreditar os mecanismos reconhecidos de evitar mortes é uma forma de promover mortes, uma vez que está enraizado dentro das tecnologias de governar.

E as estatísticas, aí sim, chamo atenção para alguns tipos de tecnologias que podem gerar a reificação das mortes e a desumanização do fato que está por trás do número. A estatística pode funcionar muito dessa forma. Do mesmo jeito que é estranho que não estejamos nos escandalizando com as mortes, conseguimos facilmente acompanhar as curvas que são mostradas nos jornais. As curvas de variação do número de mortos são vistas como se não representassem verdadeiros dramas humanos. Aceitamos discutir sobre as técnicas usadas para contabilizar a tragédia, a partir de dados brutos diários ou de uma média flutuante. No dia seguinte, a "média flutuante" já entrou no vocabulário das discussões, e estamos falando da estatística, e não das pessoas. É uma forma eficaz de coisificar, ou reificar uma realidade muito dura, muito drástica. 
Simone, agora me lembrei, já que estamos falando em normalização, uma das coisas predominantes quando começaram as discussões sobre a pandemia era o debate sobre "o que vem depois". Ele estava mais aceso no início do que agora. Acho que faz parte do processo de normalização, as pessoas descansarem um pouco de tentar adivinhar o que vem pela frente.

Quando você observa o que pode surgir em termos de estruturas do Estado para lidar com a desigualdade, a história das grandes políticas de redução das desigualdades — não em todo lugar e nem em todo tempo - é marcada por períodos de crise. O que quero dizer com isso? Você pensa no processo de formação do Estado de bem-estar social, de suas políticas centrais, elas nunca emergem por um processo de incremento. São sempre situações muito específicas em que emerge uma sensibilidade derivada de uma situação incomum, em que todo mundo está lidando com aquilo que tem um sentido de urgência, então um determinado tipo de medida é tomada, às vezes, em caráter emergencial, mas se transforma numa coisa mais longeva, passando a constituir uma estrutura. Consequentemente ganha um sentido de inércia, que faz com que se torne muito difícil mudar as estruturas que lidam com a situação que antes era vista como emergencial.

Essa é a história das políticas que lidam com pobreza, desigualdade, com os problemas sociais de um modo geral. E diante da pandemia, eu estava muito atento, pensando que alguma coisa desse tipo, uma situação dessas, pudesse surgir. Me parece que estamos diante de algo assim. Se adotou um auxílio emergencial que abrange uma quantidade de pessoas muito maior do que um programa de transferência de renda, como o Bolsa Família, e na média, o benefício é muito mais alto. Isso tem um efeito, inclusive político. Tem um efeito na forma de lidar com o problema inicial, e a necessidade da sua retirada é um problema político para quem adotou a medida.

Então, já existe na mesa, algo sendo negociado por diferentes correntes políticas: a possibilidade de que esse auxílio possa, talvez, num nível mais baixo, se transformar em algo permanente. Aí eu fico pensando, quando se está discutindo mudança na estrutura de impostos, imagina se houvesse de fato uma comoção nacional acerca da tragédia que são os nossos índices de desigualdade. Se isso realmente constituísse um discurso político, haveria uma comoção generalizada. Qualquer proposta que não tocasse de maneira muito forte na desigualdade, seria rechaçada. Ou pior, qualquer proposta que demonstrasse alguma chance de agravar a desigualdade seria negada, mas estamos muito 
distantes disso. O fato de não politizarmos o problema, de não o trazermos para o debate do dia, fará com que o problema da desigualdade gere, por exemplo, um debate estéreo do ponto de vista político sobre desigualdade. Esse problema tão sério vai passar ao largo da discussão sobre reforma tributária. Como se o Brasil fosse a Bélgica. Arriscamos discutir impostos como se não tivéssemos essa mazela desde sempre.

\section{Simone Brito:}

Ed Júnior, diz: — Se, como você afirma, a forma como lidamos/toleramos nossas desigualdades se equipara ao tratamento dado à pandemia, como, então, combater esse contexto de apatia usando a sociologia como ferramenta?

E no mesmo sentido, Cláudio Alves pergunta se investigar contra movimentos sociais, na história da luta dos movimentos sociais no Brasil, pode fecundar respostas para a naturalização das desigualdades no Brasil.

Também tenho uma pergunta, trata do que você tinha falado antes, mas é pensando na sua outra área de pesquisa: os movimentos sociais. Por que uma questão tão central e estruturante da nossa vida, como a questão da desigualdade social, é tão difícil de se tornar um elemento articulador dos movimentos sociais? Por que ela sempre é colocada, mas mitigada como questão? Acho até que é considerado meio antipático o partido que vem com essas grandes discussões, porque pareça muito acadêmico. Mas a minha pergunta é pensando na sua perspectiva sobre os movimentos sociais. Por que é difícil colocar isso na pauta?

\section{Rogério Medeiros:}

Como combater a apatia com a sociologia? Eu acho que existem muitas formas de responder a essa pergunta. Eu tendo a pensar a sociologia como parte da própria sociedade. A sociologia é uma das formas da sociedade se ver. A crítica social é parte integrante de todos os processos gestados na sociedade. Uma sociedade capaz de gerar críticos, é uma sociedade capaz de ter reflexividade, de pensar sobre a sua própria condição. Eu sei que, às vezes, tendemos a pensar de uma maneira um pouco mais aplicada, como se a sociologia fosse uma espécie de ferramenta. Então, de um modo muito amplo, eu diria que a sociologia constitui um tipo de ação, de atividade, que a própria sociedade gesta para poder encontrar caminhos, perceber problemas não vistos imediatamente. É parte da própria crítica da 
sociedade sobre si mesmo. Agora, em um sentido muito mais prático, podemos dizer que a sociologia, produzindo conhecimentos sobre essas dinâmicas, nem sempre visíveis, está em si contribuindo para resolver problemas práticos.

Se fizermos um paralelo, e eu sei que isso nem sempre funciona. Mas vejamos... se para criarmos uma vacina contra a COVID-19, é preciso que pesquisas em biologia pura e aplicada se desenvolvam por muito tempo; para que se ache uma solução, por exemplo, de política pública para as nossas desigualdades, é preciso saber dos mecanismos que geram essas desigualdades. A sociologia tem dado contribuições, tem lançado luzes renovadas sobre esses processos. Então os estudos de estratificação social, de estrutura social no Brasil têm uma certa tradição, têm mostrado coisas interessantíssimas no meio da pandemia, coisas que eu não tenho visto em outro lugar.

Tem um grupo muito interessante estudando a desigualdade durante a pandemia recomendo a leitura. Saiu uma matéria recentemente, numa série especial do jornal Nexo, ${ }^{17}$ descrevendo como alguns especialistas em estratificação social no Brasil tentaram mostrar, de um modo muito evidente, porque alguns indicadores que são normalmente usados para medir desigualdade ou melhoria dos cenários em diversos setores da sociedade, precisam ser lidos de outras formas em um momento não normal como o que estamos vivendo.

Por exemplo, é possível observar o desemprego e perceber melhorias nesses indicadores agora, e eles vão em cima dos detalhes desses indicadores, mostrando que existem processos acontecendo agora que não acontecem em situação de normalidade, e que, portanto, esses dados sobre emprego/desemprego precisam ser todos qualificados e ponderados por conta da situação anormal em que eles estão se expressando. São exemplos: os indicadores de emprego e desemprego, os indicadores de redução de pobreza, entre outros. Esse é um tipo de conhecimento que revela como os sociólogos estão buscando caracterizar a situação social, dando uma contribuição muito interessante, muito significativa.

Outro exemplo: Simone e eu temos conversado, já faz algum tempo, sobre uma leitura que precisa ser tratada de uma maneira mais sistemática acerca das formas como os governos têm respondido a essa crise, que parece indicar coisas que não estão sendo ditas,

\footnotetext{
${ }^{17}$ PRATES, Ian; BARBOSA, Rogério J. Desigualdade, pobreza e a normalização do absurdo. Jornal Nexo, publicado em 22/06/2020. Disponível em: https://www.nexojornal.com.br/ensaio/debate/2020/ Desigualdade-pobreza-e-a-normaliza\%C3\%A7\%C3\%A3o-do-absurdo. Acesso em: 21 jan. 2021.
} 
que não estão sendo tratadas, que são processos que, ao olho treinado, já demonstram regularidades, precisam ser destrinchados, para que isso vire evidências e assim por diante. São coisas que podemos fazer. Se isso vai ou não virar ferramenta para os grupos que têm algum poder de transformar politicamente; se isso vai fazer parte de uma disputa política e assim transformar os rumos, a gente não sabe dizer. Na verdade, dificilmente uma pessoa que produz ciência, que produz conhecimento, tem condições de saber o uso que será feito desse conhecimento. A inexistência do conhecimento é a certeza de que esse potencial nunca será usado. Se existe o conhecimento, ele pode ser utilizado. Eu acho que existe um papel para a sociologia nisso tudo. Essa é a resposta mais direta. É tentar identificar exatamente as dinâmicas e os processos que nem sempre são visíveis nos dados, na frieza dos números. Dinâmicas que podem ser explicitadas e compreendidas.

\section{Simone Brito:}

Um parêntese: algumas pessoas acreditam que a sociologia e a filosofia podem perverter a juventude. Eu acho que a gente devia ter a mesma fé que quem acredita nisso está depositando na gente. Além de tudo que você disse, a gente precisa acreditar. Se eles têm tanta fé na gente, precisamos fazer isso! Aceitar esse trabalho. Se eles estão dizendo que a gente pode, então por que vamos duvidar da gente?!

\section{Rogério Medeiros:}

Pois é. A crença parece que já existe.

\section{Simone Brito:}

Já existe. Acham que vamos fazer revolução. Por que a gente não acredita nisso?!

\section{Rogério Medeiros:}

Cláudio perguntou sobre a história dos contramovimentos para tentar encontrar caminho de respostas à naturalização das desigualdades. É uma história que ainda merece mais atenção. Eu concordo. Merece mais atenção. Aliás, pode ser até que já exista uma atenção dedicada a isso e que eu não conheça. Conhecer os movimentos políticos que resistem às tendências e às forças políticas democratizantes, progressistas. Eu acho que pode ser um caminho muito interessante também para contar essa história toda, sob uma 
perspectiva política, sob uma perspectiva da ação política direta e da contra-ação e dos contramovimentos que impedem muitas vezes que essas forças políticas alcancem resultados mais duradouros.

Temos visto nos últimos tempos, por exemplo, que cresceu visivelmente o interesse pela ascensão de uma nova direta, o surgimento de uma direita renovada, uma juventude conservadora. Imagina se identificar situações ou momentos de oportunidade política outro conceito de Charles Tilly —, em que forças contrárias às mudanças atuaram fortemente no sentido de fechar as possibilidades de transformação. Essa é uma história ainda a ser contada. Eu não duvido que tenha tido apelo significativo, talvez não tenham se configurado, se assumido ou se expressado como movimento - no caso, contramovimento —, mas forças políticas que se opuseram a mudanças, temos na nossa história com toda certeza. E temos agora também. Poderíamos estar contando essa história sob tal perspectiva também. Eu concordo com você.

Simone pergunta por que a questão da desigualdade não é a grande questão dos movimentos? É difícil responder a isso de uma maneira abstrata. Por que estou dizendo que seria complicado responder em abstrato? Porque devemos considerar que existem diferentes aspectos de um movimento social. Existem teorias que vão tentar explicar por que motivos eles emergem, enquanto outras vão explicar como é que eles sucedem, como é que eles impactam a sociedade; outras refletem sobre o que é necessário para que um movimento realmente consiga alcançar transformações duradouras.

Algumas teorias, que tratam sobre porque os movimentos emergem, vão dizer que sempre será necessário que alguma situação inicialmente difusa ou indeterminada seja traduzida em termos de um problema específico e vire de fato uma luta. Charles Tilly fala disso, Sidney Tarrow também, mas alguém como Alberto Melucci, que representa outra corrente, vai argumentar a mesma coisa, ou o próprio Jeffrey Alexander, que ao tratar de movimentos sociais afirma que o papel do social é operar uma tradução. É traduzir uma situação difusa, ou, às vezes, uma situação muito particularista no discurso universalista de uma sociedade civil, que tem temas abrangentes, que se configuram como valores abrangentes. Então o movimento social funcionaria como uma espécie de tradutor, capaz de gerar a possibilidade de mobilização, gerar identidade e identificação, tornar plausível que um determinado esforço coletivo promova essas transformações que o movimento defende. O movimento social lida sempre com isso, tanto em termos discursivos quanto na 
forma como ele consegue incidir em estruturas capazes de gerar resultados imediatos que sirvam como exemplo, que retroalimentem a sua mobilização.

Quando partimos dessas ideias para pensar o que acontece no Brasil, temos as desigualdades sociais como um fenômeno tão abrangente, tão básico, que é difícil que ele seja dramatizado como um evento. Quando Manuel Castells fez uma análise sobre aqueles movimentos da primavera Árabe, do Occupy Wall Street e outros - e fez isso em um ensaio, ${ }^{18}$ não no formato de um estudo sociológico em sentido estrito - , ele tenta enxergar, por exemplo, coisas comuns àqueles movimentos. Ele identifica uma espécie de gatilho, de algum tipo de dramatização que constitui algo que encena a ideia de um trauma que requer ou exige reparação; aquilo vira um motor gigantesco de mobilização, pois é a comoção que se estabelece, que se instaura.

E talvez a desigualdade seja um fenômeno tão abrangente, tão entranhado em tudo o que fazemos, em tudo o que somos, são dramas tão gráficos, tão visíveis, que mesmo assim não se transformaram necessariamente em comoções nacionais. Uma família é metralhada com oitenta tiros, ${ }^{19}$ sendo absolutamente inocente, e isso não vira uma comoção nacional! Imagina um tema tão difuso, mas não menos importante, que está na base de tudo isso, ser encenado ao ponto de parecer algo sobre o qual vale a pena incidir numa ação direta, que vale a pena sair de casa, mobilizar, perder o almoço, chamar gente, convencer pessoas, andar, correr, gritar, fazer cartazes, o que quer que seja, o que quer que esteja envolvido em toda mobilização. Eu responderia nessa direção. Seria uma forma de compreender a ausência das desigualdades da ação direta dos movimentos.

Por outro lado, tem outra coisa que eu acho que valeria a pena chamar a atenção. $\mathrm{O}$ sociólogo italiano Alberto Melucci tem um livro muito famoso, $A$ invenção do presente, ${ }^{20}$ em que ele detalha a sua teoria sobre os movimentos sociais, sobre o papel das identidades na construção de um movimento, o papel das emoções, entre outros elementos. Mas tem uma passagem em que ele diz uma coisa que eu acho incrível. É algo inclusive que já tinha sido dito antes dele, mas não da mesma forma, com a mesma concisão. Ele diz que o

${ }^{18}$ CASTELLS, Manuel. Redes de indignação e esperança: movimentos sociais na era da internet. Rio de Janeiro: Zahar, 2013.

19 "Exército dispara 80 tiros em carro de família no Rio e mata músico". Folha de São Paulo, publicado em 08/04/2019. Disponível em: https:/www1.folha.uol.com.br/cotidiano/2019/04/militares-doexercito-matam-musico-em-abordagem-na-zona-oeste-do-rio.shtml. Acesso em: 21 jan. 2021.

20 MELUCCI, Alberto. A invenção do presente: movimentos sociais nas sociedades complexas. Petrópolis: Vozes, 2001. 
movimento social não pode ser pensado como apenas uma resposta a uma crise, mas ele sempre revela uma contradição. Com isso, poderíamos presenciar o surgimento de um movimento social e, superficial e mecanicamente, deduzir que aquilo seria uma reação mais ou menos racional a um estado de crise, talvez uma situação de privação material momentânea, de injúria moral ou qualquer coisa desse tipo. Ele considera que nem sempre é isso que ocorre. Uma simples reação. Por outro lado, uma coisa que sempre acontece é que ele antecipa uma contradição, que pode estar latente e nunca ter sido evidenciada. Eu escutei algo parecido da própria Vera Telles, na última reunião da ANPOCS, em 2019. Quando alguém perguntou a ela sobre como é que ninguém anteviu esse estado de coisas, quer dizer, a ascensão desse tipo de grupo político ao poder, à frente de uma política tão regressiva, ela disse: "eu acho que nós esquecemos de buscar, na verdade, contradições e tensões muito subterrâneas, que nós inclusive já tivemos costume de fazer isso no passado, mas que nós nos distanciamos um pouco dessas coisas, de tentar perceber essas contradições, essas tensões mais ou menos ocultas nas tramas do dia a dia.”

Se a gente olhar para trás, para 2013 no Brasil, tinha uma tensão latente ali, que explodiu de maneira muito difusa; e aquilo foi passo a passo se cristalizando em determinados discursos, constituindo opinião pública, foi hegemonizando alguns discursos na mídia, e a população foi aceitando, e virou, publicamente, uma grande insatisfação com o governo e deu combustível para o que veio em seguida, com o golpe contra a Dilma. Nós não antevimos isso, de fato.

Aqui no PPGS, tivemos duas teses sobre 2013, ${ }^{21}$ sendo defendidas entre 2013 e 2015. O máximo que conseguimos enxergar naquele momento com as teses foi que grupos que nunca tinham se apresentado com aquelas características num ambiente público, se apresentaram. Algumas pessoas chamavam de grupos autonomistas, outros chamavam de proto-nova-direita, juventude de direita. Mas não conseguíamos ver aquilo como um reflexo de uma grande tensão estrutural. No que isso tudo vai dar a gente não sabe, mas parece que os movimentos antecipam algumas coisas que estão meio escondidas, latentes.

${ }^{21}$ Me refiro ao conjunto das manifestações coletivas que tomaram as ruas do Brasil no ano de 2013. 


\section{Simone Brito:}

Obrigada, Rogério. Não há mais perguntas, apenas comentários; alguns pedindo para você compartilhar as referências citadas. Parabéns pela exposição. Tentando concluir, eu queria agradecer pela palestra. É a primeira vez que faço duas mediações seguidas, e gostei de fazê-las. Acho que - quebrando o protocolo —, geralmente, mediação é uma coisa meio chata. Mas, não foi o caso em nenhum dos dois dias. ${ }^{22}$ Tanto na semana passada quanto hoje, foi bem interessante ver os caminhos que vocês escolheram para tocar em pontos que são muito urgentes. Destacando que eu concordo muito com o ponto que você chamou atenção na última parte de sua fala: o limite, de fato, que nós temos, a impossibilidade da nossa ciência de fazer previsões. É da natureza da nossa ciência tomando emprestado do Giddens - que, enquanto estamos tentando compreender, também já estamos transformando o processo. Então, discussões como essa trazem um elemento valioso de compreensão e de transformação do cotidiano. Dentro das ciências sociais, muitas vezes, esses elementos estão meio desordenados, daí a importância do fio condutor que você nos trouxe hoje. Na semana passada, foi o autoritarismo, e hoje, foi a desigualdade. São temas importantes para os debates.

Uma última coisa a falar, já pensando na conclusão. Trata-se da interseccionalidade, tema que você está trabalhando atualmente e que pode ser vista sob várias perspectivas. Gostaria de ouvi-lo um pouco mais sobre a perspectiva que você adota. Claramente, esta é uma questão mais técnica, voltada especialmente para as ciências sociais, o que seria interessante, considerando que a maioria do nosso público é da área. Como você percebe os ganhos que essa perspectiva traz para a percepção que temos hoje? Por exemplo, o que é diferente desses instrumentos para como nós percebíamos a questão há vinte anos? Aqui eu concluo, pois estamos chegando ao momento de finalizar.

\section{Rogerio Medeiros:}

Obrigado, Simone. Para contextualizar, quero dizer umas coisas. No último semestre, no Programa Pós-Graduação em Sociologia, eu ofertei uma disciplina chamada: "Perspectivas interseccionais sobre as desigualdades". Então eu trabalhei o conceito de interseccionalidade direcionando-o ao tema das desigualdades. Eu cheguei a esse termo, a

\footnotetext{
${ }^{22}$ A professora Simone Brito também mediou a palestra que antecedeu esta, proferida pelo professor José Henrique Artigas de Godoy, como parte do mesmo seminário.
} 
esse conceito, por necessidade. É um conceito que interpela muito a prática das ciências sociais. Eu vinha fazendo uma pesquisa sobre pobreza na periferia de João Pessoa, estudando os grupos beneficiários do Programa do Bolsa Família. Era um desenho de pesquisa com o qual eu buscava capturar exatamente variação, variabilidade no comportamento das categorias. Eu procurava explodir a categoria de ‘beneficiário’ em dez ou doze perfis distintos, e procurava captar variação nos efeitos da política Bolsa Família; os resultados foram imensamente complexos. Quando eu tentava fazer relações, por exemplo, entre questões de gênero e pobreza, raça e pobreza, origem rural e urbana, tempo de imigração, era uma coisa maluca.

E nessa época, eu estava dando um curso sobre metodologia, e nesses estudos, aparecia a interseccionalidade como uma proposição conceitual, mas também metodológica. E o que aquilo abria como crítica? Como crítica, porque é um tipo de conceito que emerge como parte de um movimento político, emerge dentro das discussões feministas, uma crítica do movimento negro e do movimento feminista negro à universalidade da categoria mulher. Isso vai gerando a necessidade de se considerar essas categorias como co-constitutivas. E aí o debate é bem longo do ponto de vista político. Pegando um atalho, já que você perguntou sobre os ganhos dessa perspectiva nos estudos sobre desigualdades, estou chegando aonde tudo isso me levou. Tem uma coisa nos estudos sobre interseccionalidade que é particularmente poderosa, que se coloca como uma possibilidade, mas antes aparece como um desafio, uma necessidade de relacionarmos processos que são diretamente ligados a áreas, categorias indenitárias e estruturas sociais.

Certas categorias quando são pensadas segundo uma metodologia convencional, são concebidas como autoimpostas ou, de outro modo, atribuídas de fora. Elas precisam, na verdade, ser pensadas como as duas coisas ao mesmo tempo. A própria identidade derivada de uma categoria como raça, por exemplo, traz essas duas propriedades operando permanentemente. A maneira como isso está relacionado com estruturas, de códigos culturais à representação simbólica abrangente, do que é o negro, do que é a mulher negra, e como isso impacta na possibilidade de você superar lugares de opressão, abriu um leque muito grande de possibilidades. Então o tema acaba desafiando a maneira como fazemos as coisas. Por exemplo, é absolutamente insuficiente, na perspectiva da interseccionalidade, que a gente lide com uma categoria central e que as outras apareçam como elementos adicionais. A categoria central determinando um lugar de opressão ou de dominação seria 
gênero, por exemplo, e as demais aparecem como qualificativos de gênero. Isso é o que se chama dentro do campo de um "método aditivo", e ele é absolutamente insuficiente na medida em que não enxerga como essas variáveis são adicionadas, são, na verdade, coconstitutivas. Às vezes, anterior, às vezes prevalente no conceito, no contexto em que o fenômeno se dá. Então não tem por que considerar antecipadamente que uma categoria é mais predominante do que outras. É o campo que tem que mostrar que naquele contexto, numa determinada situação de dominação, tem tal elemento como o mais forte, o mais evidente, saliente. Então assim, é considerado como necessário que o desenho da pesquisa tenha essa questão pelo menos em aberto, precisa ser colocado como uma possibilidade em aberto, ao invés de estar preconcebido, pressuposto, no próprio desenho do estudo. Mas a característica que eu considero como central para os estudos sobre desigualdades está nessa possibilidade, e necessidade, de relacionar estruturas sociais com processos meso ou micro.

Alguns estudos têm tentado fazer isso no campo da sociologia, desde textos teóricos até proposições propriamente metodológicas. Há um texto muito bom, que tratamos nessa disciplina, de duas pesquisadoras da universidade de Wisconsin, ${ }^{23}$ nos EUA, que fazem um balanço de estudos bem-conceituados produzidos sobre desigualdade, e tentam ver que no campo da sociologia, o uso da interseccionalidade implica necessariamente em três tipos de ênfase: são estudos que se voltam para estudar processos, grupos ou estruturas, e, às vezes, fazem isso de forma combinada. Se um dado problema de pesquisa, na forma como está recortado, exige estrutura e processo, estrutura e identidades, grupos, fechamento de grupos e estrutura sociais, cada uma dessas ênfases pode ser mobilizada e combinada na análise. É bem interessante para enxergarmos como isso tem operado dentro da sociologia.

Quem tem um texto muito interessante, que é quase um roteiro de elaboração de um estudo sobre desigualdades em uma perspectiva interseccional, no campo da sociologia disposicional, é Patrícia Mattos. ${ }^{24}$ Ela argumenta que a perspectiva interseccional vai poder suprir uma lacuna que os estudos de sociologia disposicional, do tipo praticado por Bernard Lahire, por exemplo, não conseguem dar conta, que é a tentativa de vincular níveis distintos

\footnotetext{
${ }^{23}$ CHOO, Hae Yeon; FERREE, Myra Marx. Practicing intersectionality in sociological research: A critical analysis of inclusions, interactions, and institutions in the study of inequalities. Sociological theory, New York, v. 28, n. 2, p. 129-149, 2010.

${ }^{24}$ MATTOS, Patrícia. As abordagens da sociologia disposicional e da interseccionalidade: articulando uma proposta para os estudos de gênero. In: BODER, Klaus (Coord.). Cultura, sociedade y democracia em America Latina: aportes para um debate interdisciplinario. Frankfurt: Iberoamericana Editorial Vervuert, 2012, p. 251-270.
} 
da realidade social para dar conta de um processo causal mais complexo, do que se concentrar sempre em um fator, em uma variável principal etc. Então isso é uma das coisas que têm sido trabalhadas. E assim você, às vezes, tem ao mesmo tempo elementos de cunho econômico, junto com elementos que tem a ver com representações culturais, e tem vários outros modelos de análise derivados do conceito de interseccionalidade. Por exemplo, a centralidade da localização social, a centralidade de uma visão radicalmente processual, e aí segue. Foi isso que gerou essa preocupação na minha tentativa de trabalhar com o conceito de interseccionalidade.

\section{Simone Brito:}

Obrigada, Rogério. Obrigada aos estudantes e aos colegas. A Nino por ter nos ajudado no processo, e ao público em geral.

Esta é a última palestra do seminário. Tentarei fazer um fechamento breve. Falando em nome do Departamento de Ciências Sociais, representando Patrícia Ramiro e Mónica Franch (chefes do departamento), quero agradecer a Rogério, obviamente, por hoje, mas também a todos os professores, palestrantes e mediadores que participaram durante todo $o$ seminário. Tivemos uma excelente resposta do público, o que é uma alegria para o departamento como um todo, para todo mundo que se envolveu e trabalhou para que os seminários acontecessem. Agradeço também a Edson (secretário do departamento), que foi fundamental para a organização deste seminário.

E agora, em nome dos professores, também é importante agradecer à chefia, porque tem sido um momento muito complexo. Apesar de, aparentemente, a universidade estar parada, o trabalho está cada vez mais intenso. Temos muitas demandas, problemas e, consequentemente, reuniões. Agradeço à chefia pela organização e pela forma tranquila como o processo foi conduzido.

Estamos felizes com o resultado. Felizes, mas sem esquecer que vivemos tempos sombrios. Por isso, espaços como este, voltados para o debate, são importantes e necessários. O nosso departamento, mesmo com a crise, conseguiu se organizar para engajar as pessoas em debates extremamente importantes, num debate público, sobre a realidade brasileira, voltado para nossas tradições de pesquisa e reflexões. Não é um jogo de vontades e interesses, o que se fez aqui foi retomar o caminho das pesquisas, honrando 
a tradição brasileira de pesquisa das ciências sociais, e atualizando-a a partir dos problemas atuais, procurando ampliar o debate. Espero que consigamos continuar, pois esse é o nosso lugar, o lugar das ciências sociais: estar no debate público a partir da pesquisa social e da reflexão crítica.

\section{Rogerio Medeiros:}

Só queria agradecer novamente a Simone por ter aceitado o convite para mediar o debate, mesmo já tendo mediado o da semana passada. E novamente agradeço à chefia do Departamento de Ciências Sociais, ao seu secretário, Edson, e ao meu colega Nino Amorim, que tornou tudo isso possível.

Como Simone, também estou muito satisfeito com o resultado. Acompanhei algumas das palestras, outras não pude acompanhar e sempre percebi uma participação muito qualificada do público. E hoje, particularmente foi gratificante discutir um tema que, às vezes, nós trabalhamos sozinhos, ou com poucos interlocutores diretos, e aqui nós tivemos a oportunidade de abrir essas reflexões em um ambiente bem mais abrangente. Isso é muito bom. Muito obrigado!

\section{Simone Brito:}

Obrigada ao público, boa noite para todo mundo. Que possamos nos encontrar novamente em breve em um novo ciclo de palestras. Espero que a gente também se encontre pela Praça da Alegria, em segurança!

Recebido em: 25/01/2020.

Aceito em: 08/03/2021. 